\title{
Processes governing the mass balance of Chhota Shigri Glacier (western Himalaya, India) assessed by point-scale surface energy balance measurements
}

\author{
M. F. Azam ${ }^{1,2}$, P. Wagnon ${ }^{1,3}$, C. Vincent ${ }^{4}$, AL. Ramanathan ${ }^{2}$, V. Favier ${ }^{4}$, A. Mandal ${ }^{2}$, and J. G. Pottakkal ${ }^{2}$ \\ ${ }^{1}$ IRD/UJF - Grenoble I/CNRS/G-INP, LGGE - UMR5183, LTHE - UMR5564, 38402 Grenoble CEDEX, France \\ ${ }^{2}$ School of Environmental Sciences, Jawaharlal Nehru University, 110067 New Delhi, India \\ ${ }^{3}$ ICIMOD, G.P.O. Box 3226, Kathmandu, Nepal \\ ${ }^{4}$ UJF - Grenoble I/CNRS, LGGE - UMR5183, 38041 Grenoble CEDEX, France
}

Correspondence to: M. F. Azam (farooqaman@yahoo.co.in, farooq.azam@lgge.obs.ujf-grenoble.fr)

Received: 26 April 2014 - Published in The Cryosphere Discuss.: 5 June 2014

Revised: 16 October 2014 - Accepted: 20 October 2014 - Published: 27 November 2014

\begin{abstract}
Some recent studies revealed that Himalayan glaciers were shrinking at an accelerated rate since the beginning of the 21st century. However, the climatic causes for this shrinkage remain unclear given that surface energy balance studies are almost nonexistent in this region. In this study, a point-scale surface energy balance analysis was performed using in situ meteorological data from the ablation zone of Chhota Shigri Glacier over two separate periods (August 2012 to February 2013 and July to October 2013) in order to understand the response of mass balance to climatic variables. Energy balance numerical modelling provides quantification of the surface energy fluxes and identification of the factors affecting glacier mass balance. The model was validated by comparing the computed and observed ablation and surface temperature data. During the summer-monsoon period, net radiation was the primary component of the surface energy balance accounting for $80 \%$ of the total heat flux followed by turbulent sensible (13\%), latent $(5 \%)$ and conductive (2\%) heat fluxes. A striking feature of the energy balance is the positive turbulent latent heat flux, suggesting re-sublimation of moist air at the glacier surface, during the summer-monsoon characterized by relatively high air temperature, high relative humidity and a continual melting surface. The impact of the Indian Summer Monsoon on Chhota Shigri Glacier mass balance has also been assessed. This analysis demonstrates that the intensity of snowfall events during the summer-monsoon plays a key role on surface albedo (melting is reduced in the case of strong snowfalls covering the glacier area), and thus is among the most
\end{abstract}

important drivers controlling the annual mass balance of the glacier. The summer-monsoon air temperature, controlling the precipitation phase (rain versus snow and thus albedo), counts, indirectly, also among the most important drivers.

\section{Introduction}

Himalayan glaciers, located on Earth's highest mountain range, are source to numerous rivers that cater to the water needs of millions of people in Asia (e.g. Kaser et al., 2010; Immerzeel et al., 2013). Recent studies have reported negative mass balances over Himalayan glaciers (e.g. Bolch et al., 2012; Kääb et al., 2012; Gardelle et al., 2013), in line with the observation that the Himalayan glaciers $\left(22800 \mathrm{~km}^{2}\right)$ have been shrinking at an accelerated rate since the beginning of the 21st century (Bolch et al., 2012). Glacial retreat and significant mass loss may not only cause natural hazards such as landslides and glacier lake outburst floods but also increase the spectre of shrinking water resources in the long term (Thayyen and Gergan, 2010; Immerzeel et al., 2013).

Unfortunately, data on recent glacier changes in the Himalayan region are sparse and even sparser as we go back in time (Cogley, 2011; Bolch et al., 2012) and, thus, the rate at which these glaciers are changing remains poorly constrained (Vincent et al., 2013). The erroneous statement in the Intergovernmental Panel on Climate Change (IPCC) Fourth Assessment Report (Parry et al., 2007) about the future of 
the Himalayan glaciers dragged the attention of the scientific community towards the behaviour of these glaciers in relation to climate. However, the IPCC Fifth Assessment Report (Stocker et al., 2013) stated "Several studies of recent glacier velocity change (Azam et al., 2012; Heid and Kääb, 2012) and of the worldwide present-day sizes of accumulation areas (Bahr et al., 2009) indicate that the world's glaciers are out of balance with the present climate and thus committed to losing considerable mass in the future, even without further changes in climate". A reliable prediction of the responses of the Himalayan glaciers towards future climatic change and their potential impacts on the regional population requires a sound understanding of the existing physical relationship between these glaciers and climate. This relationship can be addressed in detail by studying the glacier surface energy balance (hereafter SEB).

Comprehensive glacier SEB studies began in the early 1950s (e.g. Hoinkes, 1953) and since then our understanding of the glacier-climate relationship has substantially improved. SEB studies of the world's glaciers and ice sheets have been carried out extensively in the Alps (e.g. Klok and Oerlemans, 2002; Oerlemans and Klok, 2002), Antarctica (e.g. Favier et al., 2011; Kuipers Munneke et al., 2012), Greenland (e.g. Van den Broeke et al., 2011), and the tropics (e.g. Wagnon et al., 1999, 2001, 2003; Favier et al., 2004; Sicart et al., 2005, 2011; Nicholson et al., 2013). In High Mountain Asia, only a few studies have been carried out mainly in Tian Shan (Li et al., 2011), the Qilian mountains (Sun et al., 2014), the Tibetan Plateau (Fujita and Ageta, 2000; Yang et al., 2011; Mölg et al., 2012; Zhang et al., 2013) and the Nepalese Himalaya (Kayastha et al., 1999; Lejeune et al., 2013). Glacier SEB studies from the Indian Himalaya (covering western as well as parts of central and eastern Himalaya) are not yet available. Such SEB studies are crucial because glaciers across the Himalayan range have different mass balance behaviours (Gardelle et al., 2013), depending on their different climatic setup. For example, glaciers in Nepal receive almost all their annual precipitation from the Indian Summer Monsoon (ISM), and are summer-accumulation type glaciers (Ageta and Higuchi, 1984; Wagnon et al., 2013), while glaciers in the western Himalaya receive precipitation both from the ISM in summer and from Mid-Latitude Westerlies (MLW) in winter (Shekhar et al., 2010).

In this paper, we present a SEB analysis for Chhota Shigri Glacier, western Himalaya. This glacier is one of the best studied glaciers in the Indian Himalaya in terms of mass balance. The first mass balance measurement on this glacier was performed in 1987. Unfortunately, it was abandoned in 1989 and restarted in 2002 (Ramanathan, 2011). Between 2002 and 2013, annual field measurements revealed that the glacier lost mass at a rate of $0.59 \pm 0.40 \mathrm{~m}$ w.e. $\mathrm{a}^{-1}$ (Ramanathan, 2011; Azam et al., 2014). The volume change of Chhota Shigri Glacier has also been measured between 1988 and 2010 using in situ geodetic measurements by Vincent et al. (2013), revealing a moderate mass loss over this 2-decade period $(-3.8 \pm 2.0 \mathrm{~m}$ w.e. corresponding to $-0.17 \pm 0.09 \mathrm{~m}$ w.e. $\mathrm{a}^{-1}$ ). Combining the latter result with field measurements and digital elevation model differencing from satellite images, they deduced a slightly positive or near-zero mass balance between 1988 and $1999(+1.0 \pm 2.7 \mathrm{~m}$ w.e. corresponding to $+0.09 \pm 0.24$ m w.e. $\mathrm{a}^{-1}$ ). Further, Azam et al. (2014) reconstructed the annual mass balances of Chhota Shigri Glacier between 1969 and 2012 using a degree-day approach and an accumulation model fed by long-term meteorological data recorded at Bhuntar meteorological station $(\sim 50 \mathrm{~km}$ south of the glacier, $1092 \mathrm{~m}$ a.s.l.) and discussed the mass balance pattern at decadal scale. They also compared the decadal timescale mass balances with meteorological variables and suggested that winter precipitation and summer temperature are almost equally important drivers controlling the mass balance pattern of this glacier. A period of steady state between 1986 and 2000 and an accelerated mass wastage after 2000 were also defined.

Present studies on the climate sensitivity of western/Indian Himalayan glaciers either come from empirical analysis at decadal timescales (Azam et al., 2014) or are based on basic comparison between meteorological variables and the glacier mass balance (Koul and Ganjoo, 2010), emphasizing the lack of physical understanding of the glacier-climate relationship in this region. Therefore, a detailed analysis of the SEB yet remains underway for the western/Indian Himalayan glaciers. Use of Automatic Weather Stations (AWSs) provides the opportunity to obtain long and continuous records of meteorological data and to study the seasonal and inter-annual variations in SEB at point locations (e.g. Oerlemans, 2000; Reijmer and Oerlemans, 2002; Mölg and Hardy, 2004). The present study is focused on the SEB analysis of Chhota Shigri Glacier, using in situ AWS measurements. It involves two main objectives: (1) analysis of the glacier's micrometeorology, and (2) an analysis of the SEB components along with the change characteristic of each component so as to give an insight into the processes controlling the mass balance at point scale as well as glacier scale.

\section{Data and climatic settings}

\subsection{Study site and AWSs description}

Chhota Shigri Glacier $\left(32.28^{\circ} \mathrm{N}, 77.58^{\circ} \mathrm{E}\right)$ is a valley-type, non-surging glacier located in the Chandra-Bhaga river basin of Lahaul and Spiti valley, Pir Panjal range, western Himalaya (Fig. 1). It lies $\sim 25 \mathrm{~km}$ (aerial distance) from the nearest town of Manali. This glacier feeds Chandra River, one of the tributaries of the Indus River system. Chhota Shigri Glacier extends from 6263 to $4050 \mathrm{~m}$ a.s.l. with a total length of $9 \mathrm{~km}$ and an area of $15.7 \mathrm{~km}^{2}$ (Wagnon et al., 


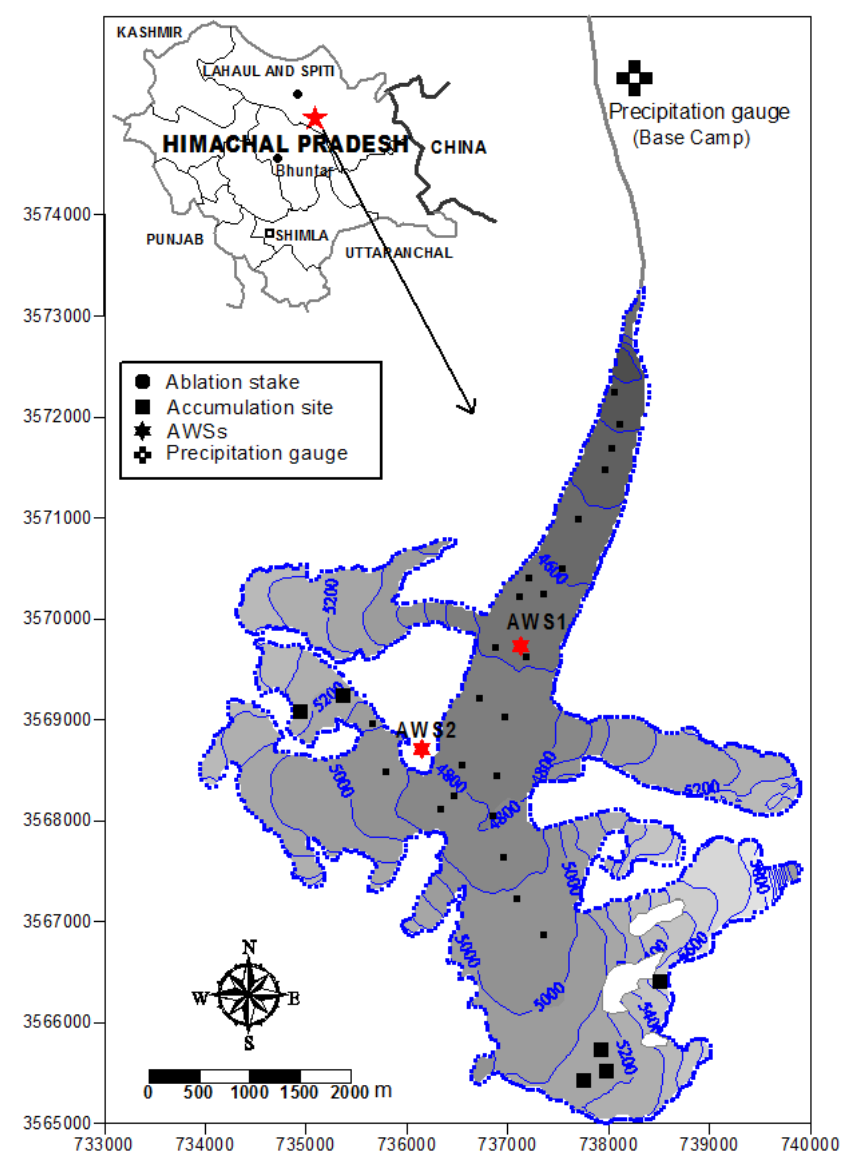

Figure 1. Map of Chhota Shigri Glacier showing the ablation stakes (black small squares), accumulation sites (black big squares), AWSs (red stars) and precipitation gauge (black cross). The map coordinates are in the UTM43 (north) World Geodetic System 1984 (WGS84) reference system.

2007). The main orientation is north in its ablation area, but its tributaries and accumulation areas have a variety of orientations (Fig. 1). The lower ablation area $(<4500 \mathrm{~m}$ a.s.l.) is covered by debris representing approximately $3.4 \%$ of the total surface area (Vincent et al., 2013). The debris layer is highly heterogeneous, from silt size to big boulders exceeding several metres. The snout is well defined, lying in a narrow valley and giving birth to a single pro-glacial stream. The equilibrium line altitude (ELA) for a zero net balance is $4960 \mathrm{~m}$ a.s.l. (Wagnon et al., 2007).

This glacier is located in the monsoon-arid transition zone and influenced by two different atmospheric circulation systems: the ISM during summer (July-September) and the Northern Hemisphere MLW during winter (January-April) (e.g. Bookhagen and Burbank, 2010). On Chhota Shigri Glacier, the hydrological year is defined from 1 October to 30 September of the following year (Wagnon et al., 2007). Since the glacier sometimes experiences some melting even in October, it would have been more appropriate to start the hydrological year at the beginning of November.
Nevertheless, for practical reasons (access to the glacier is impossible after mid-October) and in view of the fact that both October and November are usually characterized by a non-significant mass balance, starting the hydrological year at the beginning of October does not change the results.

Two meteorological stations (AWS1 and AWS2) have been operated on Chhota Shigri Glacier (Fig. 1). AWS1 was operated between 12 August 2012 and 4 October 2013, in the middle of ablation zone ( $4670 \mathrm{~m}$ a.s.l.) on an almost horizontal and homogeneous surface while AWS2 is located off-glacier on a western lateral moraine (4863 m a.s.1.), functioning continuously since 18 August 2009. At AWS1 and AWS2, meteorological variables were recorded as halfhourly means with a $30 \mathrm{~s}$ time step, except for wind direction (half-hourly instantaneous values), and stored in a Campbell CR1000 data logger. AWS1 was equipped with a tripod standing freely on the glacier with wooden plates at the base of its legs and sinks with the melting surface. AWS2 provides pluri-annual meteorological data (from 2009 to 2013) allowing the characterization of the seasons as well as the analysis of the local climatic conditions on Chhota Shigri Glacier. Both AWS1 and AWS2 were checked and maintained every month during the summers (accessibility in winter was not possible). At the glacier base camp (3850 ma.s.1.), an all-weather precipitation gauge with a hanging weighing transducer (Geonor T-200B) has been operating continuously since 7 July 2012 (Fig. 1). The Geonor sensor is suitable for both solid and liquid precipitation measurements. Table 1 gives the list of meteorological variables used in this study, with the sensor specifications.

\subsection{Meteorological data and corrections}

Only AWS1 data were used for SEB calculations. During winter, the lower sensors $\left(T_{\text {air }}, \mathrm{RH}, u\right)$ were buried under heavy snowfalls on 18 January 2013, and AWS1 stopped operating completely on 11 February until 7 July 2013 when the glacier was again accessible and AWS1 could be repaired. To ensure good data quality, the period between 4 and 11 February 2013 was eliminated as this period was supposed to be influenced by near surface snow. Thus, complete data sets of 263 days in two separate periods (13 August 2012 to 3 February 2013 and 8 July to 3 October 2013) are available for analysis, except for sensor SR50A, for which data are also missing from 8 September to 9 October 2012. The records from AWS2 have very few data gaps $(0.003,0.29$, and $0.07 \%$ data gaps over the 4-year period for $T_{\text {air }}, u$ and WD, respectively). These gaps were filled by linear interpolation using the adjacent data. Only one long gap exists for LWI data between 18 August 2009 and 22 May 2010.

Radiation fluxes are directly measured in the field (Table 1), however several corrections were applied to these data before using in the SEB model. Night values of SWI and SWO were set to zero. At high elevation sites, such as the Himalaya, measured SWO can be higher than SWI ( $2.6 \%$ of 
Table 1. Measurement specifications for AWS1 located at $4670 \mathrm{~m}$ a.s.1. on the mid-ablation zone of Chhota Shigri Glacier, AWS2 located on a moraine at $4863 \mathrm{~m}$ a.s.1., and precipitation gauge installed at base camp (3850 m a.s.1.). Accumulation/Ablation at AWS1 was measured by SR50A sensor (Sect. 2.3). Variable symbols are also given. Sensor heights indicate the initial distances to the surface (12 August 2012).

\begin{tabular}{|c|c|c|c|c|}
\hline Variable & $\begin{array}{l}\text { Symbol } \\
\text { (unit) }\end{array}$ & Sensor & $\begin{array}{l}\text { Initial height } \\
(\mathrm{m})\end{array}$ & Stated accuracy \\
\hline \multicolumn{5}{|c|}{ AWS1 } \\
\hline Air temperature & $T_{\text {air }}\left({ }^{\circ} \mathrm{C}\right)$ & Campbell HMP155A ${ }^{\mathrm{a}}$ & 0.8 and 2.5 & \pm 0.1 at $0^{\circ} \mathrm{C}$ \\
\hline Relative humidity & $\mathrm{RH}(\%)$ & Campbell HMP155A ${ }^{\mathrm{a}}$ & 0.8 and 2.5 & $\pm 1 \% \mathrm{RH}$ at $15^{\circ} \mathrm{C}$ \\
\hline Wind speed & $u\left(\mathrm{~m} \mathrm{~s}^{-1}\right)$ & A100LK, Vector Inst. & 0.8 and 2.5 & \pm 0.1 up to $10 \mathrm{~m} \mathrm{~s}^{-1}$ \\
\hline Wind direction & $\mathrm{WD}\left({ }^{\circ}\right)$ & W200P, Vector Inst. & 2.5 & $\pm 2^{\circ}$ \\
\hline Incoming and outgoing shortwave radiations & SWI, SWO $\left(\mathrm{W} \mathrm{m}^{-2}\right)$ & Kipp \& Zonen CNR-4 & 1.8 & $\pm 10 \%$ day total \\
\hline Incoming and outgoing longwave radiations & LWI, LWO $\left(\mathrm{W} \mathrm{m}^{-2}\right)$ & Kipp \& Zonen CNR-4 & 1.8 & $\pm 10 \%$ day total \\
\hline Air pressure & $P_{\text {air }}(\mathrm{hPa})$ & Young $61302 \mathrm{~V}$ & 1 & $\pm 0.3 \mathrm{hPa}$ \\
\hline Accumulation/ablation & SR50A (m) & Campbell SR50A ${ }^{\mathrm{b}}$ & $1.6^{\mathrm{c}}$ & $\pm 0.01 \mathrm{~m}$ or $0.4 \%$ to target \\
\hline \multicolumn{5}{|c|}{ AWS2 } \\
\hline Air temperature & $T_{\text {air }}\left({ }^{\circ} \mathrm{C}\right)$ & Campbell H3-S3-XT & 1.5 & \pm 0.1 at $0^{\circ} \mathrm{C}$ \\
\hline Relative humidity & $\mathrm{RH}(\%)$ & Campbell H3-S3-XT & 1.5 & $\pm 1.5 \% \mathrm{RH}$ at $23^{\circ} \mathrm{C}$ \\
\hline Wind speed & $u\left(\mathrm{~m} \mathrm{~s}^{-1}\right)$ & Campbell 05103-10-L & 3.0 & $\pm 0.3 \mathrm{~m} \mathrm{~s}^{-1}$ \\
\hline Incoming shortwave radiation & $\operatorname{SWI}\left(\mathrm{W} \mathrm{m}^{-2}\right)$ & Kipp \& Zonen CNR-1 & 2.5 & $\pm 10 \%$ day total \\
\hline Incoming longwave radiation & $\operatorname{LWI}\left(\mathrm{W} \mathrm{m}^{-2}\right)$ & Kipp \& Zonen CNR-1 & 2.5 & $\pm 10 \%$ day total \\
\hline Precipitation (base camp) & $(\mathrm{mm})$ & Geonor T-200B & 1.7 (inlet height) & $\pm 0.6 \mathrm{~mm}$ \\
\hline
\end{tabular}

${ }^{\mathrm{a}}$ Aspirated during daytime with RM Young 43502 radiation shields, ${ }^{\mathrm{b}}$ mounted on a separate aluminum pole drilled into the ice, ${ }^{\mathrm{c}} 1.6 \mathrm{~m}$ was initial height for SR50A sensor.

total data here) during the morning and evening time when the solar angle is low because of poor cosine response of the upward-looking radiation (SWI) sensor (Nicholson et al., 2013). Besides, as AWS1 was installed on the middle of the ablation area, the unstable glacier surface during the ablation season conceivably gave rise to a phase shift by mast tilt (Giesen et al., 2009). The SWO sensor mostly receives isotropic radiation and consequently is much less sensitive to measurement uncertainties of poor cosine response and mast tilt compared to the SWI sensor (Van den Broeke et al., 2004). Therefore, SWI is calculated from SWO (raw) and accumulated albedo $\left(\alpha_{\text {acc }}\right)$ to avoid the impact of the phase shift because of tilting during the daily cycle of SWI and poor cosine response of the SWI sensor during the low solar angles. $\alpha_{\text {acc }}$ values were computed (Eq. 1) as the ratio of accumulated SWO (raw) and SWI (raw) over a time window of $24 \mathrm{~h}$ centred on the moment of observation using the method described in Van den Broeke et al. (2004). The obvious shortcoming of the accumulated albedo method is the elimination of the clear-sky daily cycle in $\alpha_{\text {acc }}$ (Van den Broeke et al., 2004):

$\alpha_{\text {acc }}=\frac{\sum_{24} \mathrm{SWO}}{\sum_{24} \mathrm{SWI}}$.

A correction has also been applied to longwave radiations as the air particles between the glacier surface and CNR-4 sensor radiate and influence LWI (underestimation of LWI at the surface) and LWO (overestimation). This generally occurs when $T_{\text {air }}$ is higher than $0{ }^{\circ} \mathrm{C}$ during the summer-monsoon (July to September). Figure 2a reveals a linear relation between LWO and $T_{\text {air }}$ above $0{ }^{\circ} \mathrm{C}$. Measured LWO was often found to be substantially greater than $315.6 \mathrm{~W} \mathrm{~m}^{-2}$, which is the maximum possible value for a melting glacier surface. Therefore, a correction can be done using LWO. We adopted the method described by Giesen et al. (2014) and fitted a linear function to the median values of the additional LWO (greater than $315.6 \mathrm{~W} \mathrm{~m}^{-2}$ ) for all $0.5^{\circ} \mathrm{C} T_{\text {air }}$ intervals above $0^{\circ} \mathrm{C}$, assuming that the correction is zero at $0^{\circ} \mathrm{C}$. This correction was added to LWI and subtracted from LWO (Fig. 2b) when $T_{\text {air }}$ was higher than $0{ }^{\circ} \mathrm{C}$. Corrections have half-hourly values up to $22 \mathrm{~W} \mathrm{~m}^{-2}$ for $T_{\text {air }}$ of $11^{\circ} \mathrm{C}$. Over all half-hourly periods with $T_{\text {air }}$ above $0^{\circ} \mathrm{C}$, the average correction was $6.3 \mathrm{~W} \mathrm{~m}^{-2}$.

In snow- and ice-melt models, cloud cover is investigated by computing "cloud factors", defined as the ratio of measured and modelled clear-sky solar radiation (Greuell et al., 1997; Klok and Oerlemans, 2002; Mölg et al., 2009). In the present study cloud factor is calculated by comparing SWI with solar radiation at the top of atmosphere (STOA) according to the equation: cloud factor $=1.3-1.4(\mathrm{SWI} / \mathrm{STOA})$ which represents a quantitative cloud cover estimate and ranges between 0 and 1 . The values 1.3 (offset) and 1.4 (scale factor) were derived from a simple linear optimization process (Favier et al., 2004). The cloud factor is calculated between 11:00 and 15:00 LT (local time) to avoid the shading effect of steep valley walls during morning and evening time. The theoretical value of STOA is calculated for a horizontal 


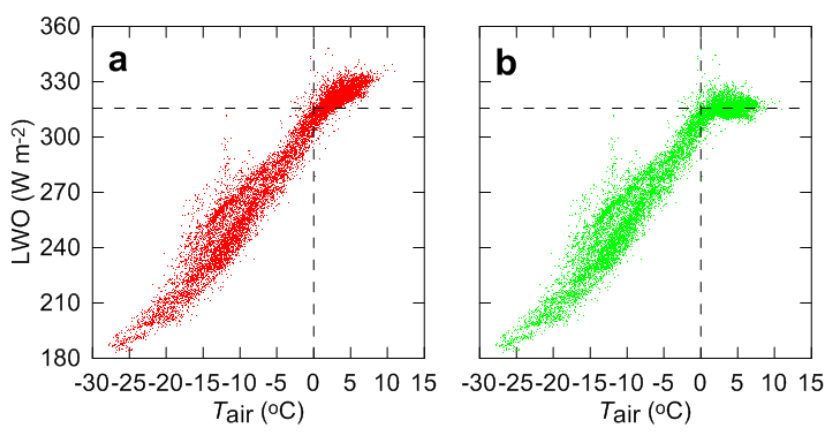

Figure 2. Half-hourly values of LWO as a function of $T_{\text {air }}$, (a) before and (b) after applying the correction for $T_{\text {air }}$ above $0{ }^{\circ} \mathrm{C}$. The dashed lines indicate $0^{\circ} \mathrm{C}$ and $315.6 \mathrm{~W} \mathrm{~m}^{-2}$, the maximum LWO for a melting surface.

plane following Iqbal (1983) and considering the solar constant equal to $1368 \mathrm{~W} \mathrm{~m}^{-2}$.

\subsection{Accumulation and ablation data}

The SR50A sensor records the accumulation of snow (decreasing the sensor distance to the surface) or the melting of ice and melting or packing of snow (increasing the sensor distance from the surface) at $4670 \mathrm{~m}$ a.s.l. close to AWS1 (Fig. 3). This sensor does not involve an internal temperature sensor to correct for the variations in speed of sound as a function of $T_{\mathrm{air}}$. Without this correction the measured distance may reduce during the evening, which could be misunderstood as a snowfall event (Maussion et al., 2011). Therefore, temperature corrections for the speed of sound were applied to the sensor output using $T_{\text {air }}$ recorded at the higher level. Also, to reduce the noise, a $3 \mathrm{~h}$ moving mean is applied to smooth the SR50A data. During the summer-monsoon on Chhota Shigri Glacier, sporadic snowfall events and followup melting may occur within hours. Therefore, the surface height variations from the $3 \mathrm{~h}$ smoothed SR50A data should be calculated over a time interval long enough to detect the true height changes during the snowfalls and short enough to detect a snowfall before melting begins. Given that SR50A measurements have an uncertainty of $\pm 1 \mathrm{~cm}$, an agreement was achieved with a $6 \mathrm{~h}$ time step between smoothed SR50 data to extract surface changes greater than $1 \mathrm{~cm}$.

Point mass balance was measured from ablation stake no. VI located at the same elevation and around $20 \mathrm{~m}$ south of AWS1. Frequent measurements, with intervals of some days to a couple of weeks, were made at stake no. VI during summer expeditions. In summer 2012, three stake measurements with intervals of 10 to 15 days were performed from $8 \mathrm{Au}$ gust to 21 September 2012, while in summer 2013, six measurements with intervals of 7 to 30 days were carried out from 8 July to 3 October 2013. By subtracting the snow accumulation assessed from SR50A measurements at AWS1 (assuming a density of $200 \mathrm{~kg} \mathrm{~m}^{-3}$ for accumulated snow), the ablation was derived corresponding to every period between two stake measurements.

\subsection{Climatic settings}

\subsubsection{Characterization of the seasons}

In this section, the meteorological conditions on Chhota Shigri Glacier, as derived from the measurements at AWS2, are described. The Himalayan Mountains are situated in the subtropical climate zone, characterized by high annual thermal amplitude, that allows a separation into summer and winter seasons. The general circulation regime over Himalaya is controlled by the Inter-Tropical Convergence Zone (ITCZ) (Bookhagen and Burbank, 2006; 2010). Figure 4 shows the mean annual cycle of monthly $T_{\text {air }}$ and RH during the 4 hydrological years, from 1 October 2009 to 30 September 2013, recorded at AWS2. The standard deviations (STDs) of mean monthly measurements were $7.0^{\circ} \mathrm{C}$ and $13 \%$ for $T_{\text {air }}$ and $\mathrm{RH}$, respectively, indicating that on Chhota Shigri Glacier, $T_{\text {air }}$ and $\mathrm{RH}$ variations are large enough to characterize pronounced seasonal regimes. A warm summer-monsoon with high relative humidity from June to September and a cold winter season, comparatively less humid, from December to March were identified. A pre-monsoon from April to May and a post-monsoon from October to November could also be defined.

Daily mean $T_{\text {air }}$ ranges between -22.0 and $+7.3{ }^{\circ} \mathrm{C}$ with a mean $T_{\text {air }}$ of $-6.0^{\circ} \mathrm{C}$ for the studied cycle (1 October 2009 to 30 September 2013), reflecting the high altitude of the AWS2 location (4863 m a.s.1.). The coldest month was January with a mean $T_{\text {air }}$ of $-15.8^{\circ} \mathrm{C}$ and the warmest month was August with a mean $T_{\text {air }}$ of $4.3^{\circ} \mathrm{C}$. Table 2 displays the mean seasonal values of all studied variables for the whole period (1 October 2009 to 30 September 2013). The summer-monsoon is warm (mean $T_{\text {air }}=2.5^{\circ} \mathrm{C}$ ) and calm (mean $u=2.8 \mathrm{~m} \mathrm{~s}^{-1}$ ) with high humidity (mean $\mathrm{RH}=68 \%$ ), whereas the winter season is characterized by cold (mean $T_{\text {air }}=-13.4^{\circ} \mathrm{C}$ ) and windy (mean $u=5.5 \mathrm{~m} \mathrm{~s}^{-1}$ ) conditions with relatively less humidity (mean $\mathrm{RH}=42 \%$ ). The mean annual RH is $52 \%$. An increase (decrease) in mean monthly $\mathrm{RH}$ in June (October) shows the onset (end) of monsoon on Chhota Shigri Glacier. Pre-monsoon and post-monsoon seasons showed intermediate conditions for air temperature, moisture and wind speed (Table 2). Although the solar angle is at its annual maximum during the summer-monsoon, SWI is the highest during the pre-monsoon with a mean value of $299 \mathrm{~W} \mathrm{~m}^{-2}$. The summer monsoonal mean is $33 \mathrm{~W} \mathrm{~m}^{-2}$ lower than the pre-monsoonal mean because of high cloud coverage in the summer-monsoon. The comparatively low values of SWI, during the summer-monsoon, are compensated by high values of LWI (Fig. 4 and Table 2) mostly emitted from warm summer monsoonal clouds. Post-monsoon and winter seasons are rather similar, receiving low and almost same SWI (176 and $161 \mathrm{~W} \mathrm{~m}^{-2}$, respectively) and LWI 

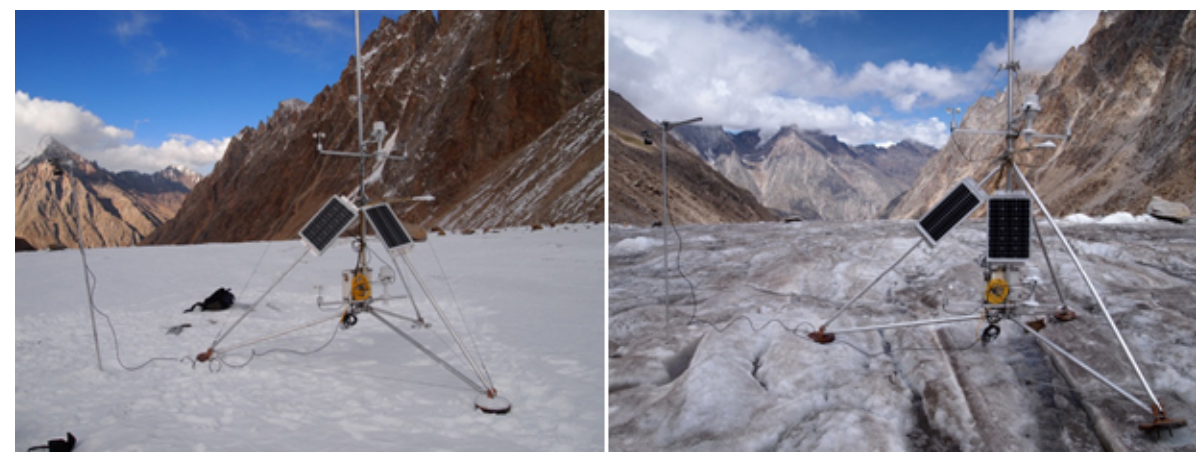

Figure 3. Photographs of AWS1 on Chhota Shigri Glacier taken on 9 October 2012 (left panel) and on 22 August 2013 (right panel) (copyright, Mohd. Farooq Azam). SR50A mounted on a separate pole drilled into the ice, is visible to the left of AWS1.

Table 2. Seasonal means and annual mean (standard deviations) of $T_{\text {air }}$, RH, $u$ and SWI over four hydrological years between 1 October 2009 and 30 September 2013 except for LWI (only three years between 1 October 2010 and 30 September 2013) at AWS2 (4863 ma.s.1.). $P$ is the seasonal precipitation for one hydrological year between 1 October 2012 and 30 September 2013 at glacier base camp collected by the Geonor T-200B.

\begin{tabular}{llllll}
\hline & $\begin{array}{l}\text { Winter } \\
(\mathrm{DJFM})\end{array}$ & $\begin{array}{l}\text { Pre-monsoon } \\
(\mathrm{AM})\end{array}$ & $\begin{array}{l}\text { Summer-monsoon } \\
(\mathrm{JJAS})\end{array}$ & $\begin{array}{l}\text { Post-monsoon } \\
(\mathrm{ON})\end{array}$ & $\begin{array}{l}\text { Annual } \\
\text { mean }\end{array}$ \\
\hline$T_{\text {air }}\left({ }^{\circ} \mathrm{C}\right)$ & $-13.4(0.9)$ & $-5.3(0.7)$ & $2.5(0.6)$ & $-7.8(1.4)$ & $-5.8(0.2)$ \\
$\mathrm{RH}(\%)$ & $42(2)$ & $52(2)$ & $68(1)$ & $39(6)$ & $52(2)$ \\
$u\left(\mathrm{~m} \mathrm{~s}^{-1}\right)$ & $5.5(0.6)$ & $3.5(0.2)$ & $2.8(0.1)$ & $4.4(0.5)$ & $4.1(0.2)$ \\
$\mathrm{SWI}\left(\mathrm{W} \mathrm{m}^{-2}\right)$ & $161(12)$ & $299(34)$ & $266(7)$ & $176(18)$ & $221(14)$ \\
$\mathrm{LWI}\left(\mathrm{W} \mathrm{m}^{-2}\right)$ & $192(3)$ & $231(2)$ & $289(17)$ & $187(8)$ & $230(6)$ \\
$P\left(\mathrm{~mm} \mathrm{w.e.}^{2}\right.$ & 679 & 148 & 117 & 32 & 976 \\
\hline
\end{tabular}

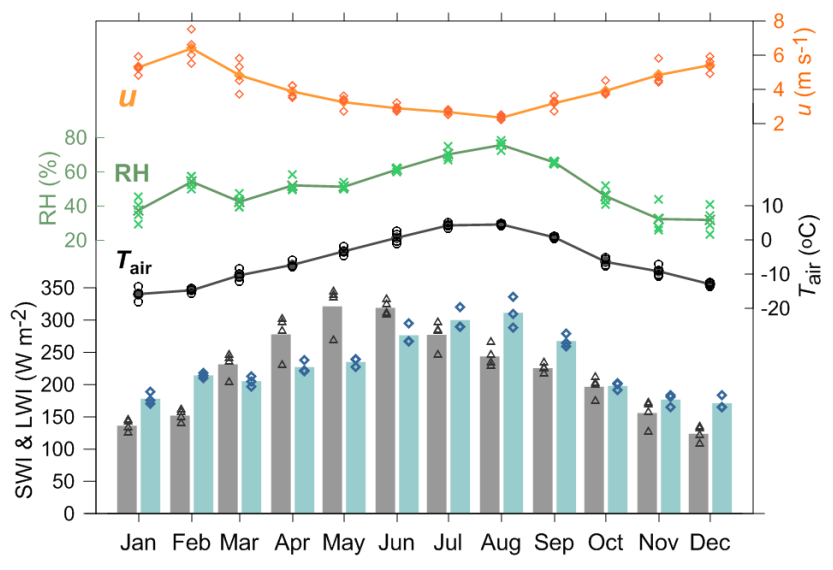

Figure 4. Mean monthly values of $T_{\text {air }}$ (black dots), RH (green crosses), $u$ (orange squares), SWI (grey bars) and LWI (light blue-green bars) at AWS2 (4863 ma.sl.). $T_{\text {air }}$, RH, $u$ and SWI are the mean monthly values of 4 hydrological years between 1 October 2009 and 30 September 2013 while LWI are the mean monthly values of 3 hydrological years between 1 October 2010 and 30 September 2013. Also shown are the monthly values of $T_{\text {air }}$ (black circles), RH (light green crosses), $u$ (orange hollow squares), SWI (black hollow triangles) and LWI (blue hollow squares) used to derive the mean monthly values.
(187 and $192 \mathrm{~W} \mathrm{~m}^{-2}$, respectively). The low SWI and LWI values over these seasons are mainly related to the decreasing solar angle (for SWI), and low values of $T_{\text {air }}, \mathrm{RH}$ and cloudiness (for LWI), respectively.

\subsubsection{Influence of ISM and MLW}

The whole Himalayan range is characterized by, from west to east, the decreasing influence of the MLW and the increasing influence of the ISM (Bookhagen and Burbank, 2010), leading to distinct precipitation regimes on glaciers depending on their location.

Figure 5 shows the monthly precipitations for a complete hydrological year between 1 October 2012 and 30 September 2013 at Chhota Shigri Glacier base camp (3850 m a.s.1.) (Fig. 1). Surprisingly, the months with minimum precipitation were July to November (mean value of $16 \mathrm{~mm}$ ) and those with maximum precipitation were January and February (183 and $238 \mathrm{~mm}$, respectively). For ease of understanding, Wulf et al. (2010) divided the distribution of precipitation over the same region into two periods: from May to October with precipitation predominantly coming from ISM and from November to April with precipitation coming from MLW. ISM contributed only $21 \%$ while MLW added $79 \%$ precipitation to the annual precipitation $(976 \mathrm{~mm})$ at Chhota 


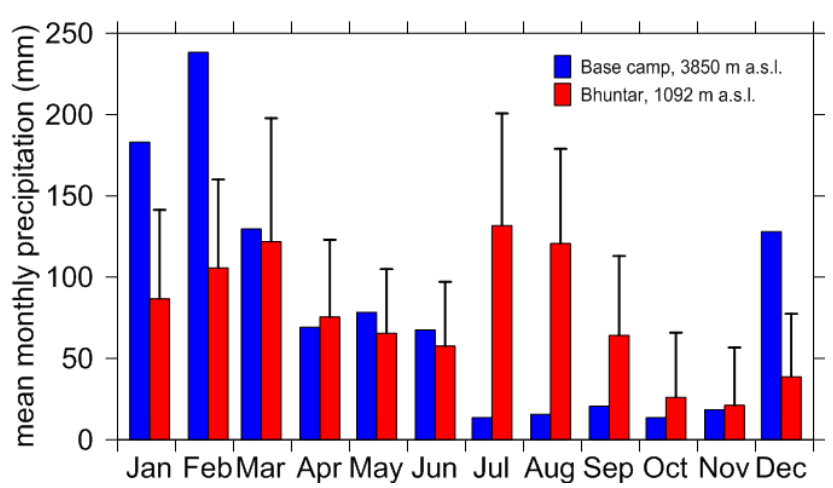

Figure 5. Comparison of monthly precipitations (blue bars) at Chhota Shigri base camp for 2012/2013 hydrological year with the mean monthly precipitations (red bars) between 1969 and 2013 at Bhuntar meteorological station. The error bars represent the standard deviation $(1 \sigma)$ of the monthly precipitation mean.

Shigri base camp for the 2012/2013 hydrological year. In Fig. 5, a comparison of 2012/2013 monthly precipitation at base camp is also done with long-term (1969-2013) mean monthly precipitations at Bhuntar meteorological station, Beas Basin (Fig. 1). Although this station is only about $50 \mathrm{~km}$ (aerial distance) from Chhota Shigri Glacier, the precipitation regime is noticeably different because ISM and MLW equally contribute to the average annual precipitation $\left(916 \mathrm{~mm} \mathrm{yr}^{-1}\right)$. The different precipitation regimes in this region can be explained by the location of the orographic barrier which ranges between 4000 and $6600 \mathrm{~m}$ in elevation (Wulf et al., 2010). ISM, coming from Bay of Bengal in the southeast, is forced by the orographic barrier to ascend, enhancing the condensation and cloud formation (Bookhagen et al., 2005). Thus, it provides high precipitation on the windward side of the orographic barrier at Bhuntar meteorological station (51\% of the annual precipitation) and low precipitations on its leeward side at Chhota Shigri Glacier (21\% of annual precipitation). In contrast to the ISM, MLW moisture derived from the Mediterranean, Black, and Caspian seas is transported at higher tropospheric levels (Weiers, 1995). Therefore, the winter westerlies predominantly undergo orographic capture at higher elevations in the orogenic interior providing high precipitations at Chhota Shigri Glacier (79\% of annual precipitation) compared to Bhuntar meteorological station on the windward side (49\% of annual precipitation). Thus, Chhota Shigri Glacier seems to be a winteraccumulation type glacier receiving most of its annual precipitation during the winter season. This precipitation comparison between glacier base camp and Bhuntar meteorological station is only restricted to the 2012/2013 hydrological year, when precipitation records at glacier base camp are available. Long-term precipitation data at glacier site are still required to better understand the relationship between the precipitation regimes prevalent on the southern and northern slopes of Pir Panjal Range.

\subsubsection{Representativeness of 2012/2013 hydrological year}

Given that long-term meteorological data at the glacier are unavailable, the representativeness of the meteorological conditions prevailing during the 2012/2013 hydrological year is assessed at Bhuntar using $T_{\text {air }}$ and precipitation data from the Bhuntar meteorological station. Figure 6a shows the comparison of 2012/2013 $T_{\text {air }}$ with the long-term mean between 1969 and 2013 at seasonal as well as annual scales. $T_{\text {air }}$ in 2012/2013 hydrological year was systematically higher for all seasons $\left(0.5,0.5\right.$ and $0.6^{\circ} \mathrm{C}$ in winter, pre-monsoon and summer-monsoon, respectively) except for post-monsoon when it was lower $\left(0.4{ }^{\circ} \mathrm{C}\right)$ than the mean seasonal $T_{\text {air }}$ over the 1969-2013 period. At the annual scale, the $2012 / 2013$ hydrological year was $0.4^{\circ} \mathrm{C}$ warmer with $T_{\text {air }}$ close to the 75th percentile of the annual mean $T_{\text {air }}$ between 1969 and 2013. Figure 6b compares the precipitation observed during the 2012/2013 hydrological year with the mean over the 1969-2013 period. In the 2012/2013 hydrological year, both ISM (May to October) and MLW (November to April) circulations brought an almost equal amount (49 and $51 \%$, respectively) of precipitation at Bhuntar meteorological station, and in that year the ISM precipitation was equal to the mean ISM precipitation over 1969-2013 whereas MLW precipitation was $5 \%$ higher than the mean MLW precipitation over the 1969-2013 hydrological years (Fig. 6b); therefore, the annual precipitation for 2012/2013 was found to be slightly higher ( $943 \mathrm{~mm}$ w.e.) than the mean annual precipitation (919 mm w.e.) over the 1969-2013 hydrological years. In conclusion, the 2012/2013 hydrological year was relatively warmer with slightly higher precipitation compared to the annual means over the 1969-2013 period. Especially concerning precipitation, the 2012/2013 hydrological year can be considered as an average year.

\section{Methodology: SEB calculations}

\subsection{SEB equation}

The meteorological data from AWS1 were used to derive the SEB at point scale. The incoming energy at the glacier surface $\left(F_{\text {surface }}\right)$ is computed following Favier et al. (2011):

$$
\begin{aligned}
\mathrm{SWI} & -\mathrm{SWO}+\mathrm{LWI}-\left[(1-\varepsilon) \mathrm{LWI}+\varepsilon \sigma T_{\mathrm{S} \_ \text {mod }}^{4}\right] \\
& +H+\mathrm{LE}=F_{\text {surface }}
\end{aligned}
$$

where SWI, SWO and LWI are the incident shortwave, outgoing shortwave and incoming longwave radiations, respectively and the term in square brackets is the modelled outgoing longwave radiation ( $\mathrm{LWO}_{\text {mod }}$ hereafter) that was deduced from the Stefan-Boltzmann equation ( $\varepsilon$ is surface emissivity, assumed to be equal to 1 for snow and ice surfaces and $\sigma=5.67 \times 10^{-8} \mathrm{~W} \mathrm{~m}^{-2} \mathrm{~K}^{-4}$ is the Stefan-Boltzmann constant) using modelled surface temperature $T_{\mathrm{S}_{-} \text {mod. }} H$ and 

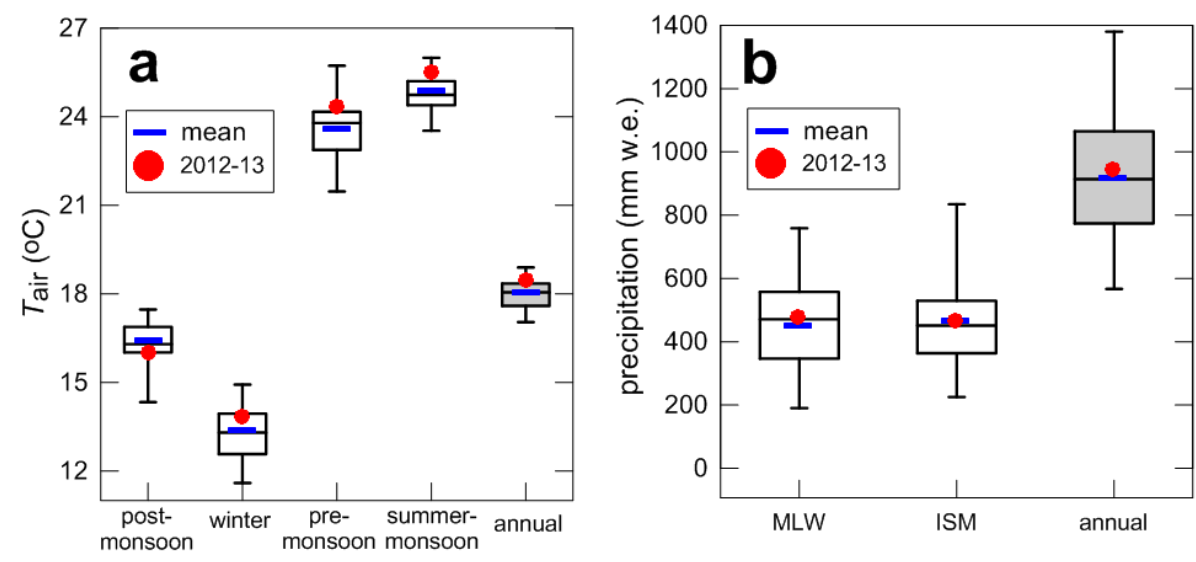

Figure 6. Boxplots of seasonal and annual $T_{\text {air }}$ (a) and precipitation (b) obtained from 44 hydrological years (1969 to 2013 ) from Bhuntar meteorological station. Boxes cover the 25 th to the 75 th percentile of each distribution with a central line as the median. The blue thick horizontal line is the 1969-2013 mean, red dot is the 2012/2013 hydrological year mean.

LE are the sensible and latent turbulent heat fluxes, respectively. The heat supplied by precipitation on glaciers is insignificant compared to the other fluxes (Oerlemans, 2001) and is therefore neglected here. The fluxes are assigned a positive value if directed towards the glacier surface or vice versa, except the outgoing radiation terms which are kept positive but assigned a negative sign as they are always directed away from the surface. For model validation, $T_{\mathrm{S}_{-} \text {mod }}$ was compared to the measured surface temperature ( $\left.T_{\mathrm{s}_{-} \mathrm{obs}}\right)$ which was derived from measured LWO using the Stefan-Boltzmann equation assuming again that the surface emissivity is unity and that it cannot exceed $273.15 \mathrm{~K}$ (Sect. 4.3).

$F_{\text {surface }}$ is the energy available at the surface. Part of the shortwave radiation is actually not available for warming/cooling or melting processes at the surface, because shortwave flux partially penetrates into the snow/ice. Hence, $F_{\text {surface }}$ is separated into two terms:

$F_{\text {surface }}=G_{0}+(1-a) \mathrm{SWN}=G_{0}+\mathrm{SW}_{\text {sub }}$,

where $G_{0}$ is the energy excess or deficit at the surface, SWN $(=\mathrm{SWI}-\mathrm{SWO})$ is the net shortwave radiation and $\mathrm{SW}_{\mathrm{sub}}$ is the shortwave radiation penetrating in the ice. In this equation, $a$ is the fractional amount of shortwave radiation that is absorbed in the top layer of the model (at the surface). When the modelled surface temperature, $T_{\mathrm{S}_{-} \bmod }$, is $0{ }^{\circ} \mathrm{C}$, the positive $G_{0}$ values represent the energy available for surface melt (mw.e.). Otherwise, this amount is used to cool/warm the frozen surface and underlying snow/ice, depending on its sign. If the subsurface ice/snow temperature exceeds $0^{\circ} \mathrm{C}$, the corresponding energy excess is converted into melt to block $T_{\mathrm{S} \_ \text {mod }}$ at $0^{\circ} \mathrm{C}$, but liquid water is assumed to be retained in the ice. When a negative surface heat budget occurs, the subsurface temperature stays at $0^{\circ} \mathrm{C}$ until this liquid water storage refreezes, and then temperature decreases. This is not the case for the surface layer where liquid water is assumed to run off and hence not be available for refreezing processes any more. Ablation is the sum of melt and sublimation (in $\mathrm{m}$ w.e.).

\subsection{Conduction into the ice/snow}

Considering that the energy conservation in the model is crucial, heat conduction (or conductive heat flux, $G$ ) into the ice/snow pack was also considered in the model. Assuming horizontal homogeneity, temperature distribution inside the ice is governed by the thermodynamic energy equation (Bintanja et al., 1997; Picard et al., 2009)

$\rho C_{\mathrm{p}-\mathrm{is}} \frac{\partial T(z, t)}{\partial t}=-K_{\mathrm{S}} \frac{\partial^{2} T(z, t)}{\partial z^{2}}+\frac{\partial \mathrm{SW}_{\mathrm{sub}}(z, t)}{\partial z}$,

where $t$ is the time, $z$ is the coordinate normal to the surface (positive downward), $\rho$ is the snow $\left(\rho_{\text {snow }}=250 \mathrm{~kg} \mathrm{~m}^{-3}\right)$ or ice density $\left(\rho_{\text {ice }}=910 \mathrm{~kg} \mathrm{~m}^{-3}\right), T(z)$ is the ice/snow temperature at depth $z, K_{\mathrm{s}}$ is thermal conductivity, $C_{\mathrm{p} \text {-is }}$ is specific heat capacity of ice/snow at constant pressure, which depends on temperature $\left(C_{\mathrm{p} \text {-is }}(\mathrm{z})=185+7.037 T(z)\right.$; Dorsey, 1940), and $\mathrm{SW}_{\mathrm{sub}}(z, t)=\mathrm{SWN}(t)(1-a) e^{-\mathrm{b} z}$ is penetrated shortwave flux at depth $z$. Bintanja et al. (1997) suggested that $a$ is 0.8 for blue ice and 0.9 for snow. Below the surface, the shortwave flux decreases exponentially with a constant extinction coefficient $b=2.5 \mathrm{~m}^{-1}$ (Bintanja et al., 1997). Distinct thermal conductivities were considered for ice $\left(K_{\mathrm{s} \text {-ice }}=2.0715 \mathrm{~W} \mathrm{~m}^{-1} \mathrm{~K}^{-1}\right)$ and snow $\left(K_{\text {s-snow }}\right)$. $K_{\text {s-snow }}$ was computed according to Douville et al. (1995), as a function of snow density. Thermal diffusion was computed through an explicit scheme to a depth of $2 \mathrm{~m}$, with a $2 \mathrm{~cm}$ layer resolution and a $20 \mathrm{~s}$ time step. Neumann limit condition was assumed at the surface (e.g. Picard et al., 2009). This boundary condition results into the following equation: 
$K_{\mathrm{s}} \frac{\partial T(z, t)}{\partial z}=-F_{\text {surface }}$,

when $G_{0}$ is not used to produce surface melt; otherwise the right side of this boundary condition equation is $-\mathrm{SW}_{\text {sub }}$. For initial conditions, we assumed that the ice was exposed (no snow at surface) and temperate (every layer was at $0{ }^{\circ} \mathrm{C}$ ) for both studied periods (in 2012 and in 2013).

\subsection{Turbulent fluxes}

\subsubsection{Turbulent flux calculations}

The major characteristic of katabatic flow is the wind speed maximum which is dependent on glacier size, slope, temperature, surface roughness and other forcing mechanisms (Denby and Greuell, 2000). Wind speed, $T_{\text {air }}$ and RH were measured at two levels (0.8 and $2.5 \mathrm{~m})$ at AWS1. At AWS1 site, $u$ at the upper level (initially at $2.5 \mathrm{~m}$ ) is always higher (99.6\% of all half-hourly data) than that at the lower level (initially at $0.8 \mathrm{~m}$ ). For the turbulent heat flux calculations, the bulk method was used. Denby and Greuell (2000) showed that the bulk method gives reasonable results in the entire layer below the wind speed maximum even in katabatic wind conditions whereas the profile method severely underestimates these fluxes. In turn, the bulk method is applied in our present study as it has already been applied in various studies where katabatic winds dominate (e.g. Klok et al., 2005; Giesen et al., 2014).

The bulk method calculates the turbulent fluxes including stability correction. This method is usually used for practical purposes because it allows the estimation of the turbulent heat fluxes from one level of measurement (Arck and Scherer, 2002). In this approach, a constant gradient is assumed between the level of measurement and the surface; consequently, surface values have to be evaluated. The stability of the surface layer is described by the bulk Richardson number, $R i_{b}$ (Eq. 5) which relates the relative effects of buoyancy to mechanical forces (e.g. Brutsaert, 1982; Moore, 1983; Oke, 1987):

$R i_{\mathrm{b}}=\frac{g \frac{\left(T_{\text {air }}-T_{\mathrm{S} \_ \text {mod }}\right)}{\left(z-z_{0 T}\right)}}{T_{\text {air }}\left(\frac{u}{z-z_{0 \mathrm{~m}}}\right)^{2}}=\frac{g\left(T_{\mathrm{air}}-T_{\mathrm{s} \_ \text {mod }}\right)\left(z-z_{0 \mathrm{~m}}\right)^{2}}{T_{\text {air }} u^{2}\left(z-z_{0 T}\right)}$,

where $z$ is the level of measurements. $T_{\text {air }}$ and $u$ are taken from the upper level $(2.5 \mathrm{~m})$ that provides a longer period for investigation. The sensor heights were extracted from SR50A records except during a data gap between 8 September and 9 October 2012. Over this period sensor heights were assumed to be constant and set as $2.5 \mathrm{~m}$, this being AWS1 in free-standing position. $g$ is the acceleration of gravity $\left(g=9.81 \mathrm{~m} \mathrm{~s}^{-2}\right) \cdot z_{0 \mathrm{~m}}$ and $z_{0 T}$ are the surface roughness parameters (in metres) for momentum and temperature, respectively. Assuming that local gradients of mean horizontal $u$, mean $T_{\text {air }}$ and mean specific humidity $q$ are equal to the finite differences between the measurement level and the surface, it is possible to give analytical expressions for the turbulent fluxes (e.g. Oke, 1987):

$$
\begin{aligned}
& H=\rho \frac{C_{\mathrm{P}} k^{2} u\left(T_{\text {air }}-T_{\mathrm{S} \_\mathrm{mod}}\right)}{\left(\operatorname{In} \frac{z}{z_{0 \mathrm{~m}}}\right)\left(\ln \frac{z}{z_{0 T}}\right)}\left(\Phi_{\mathrm{m}} \Phi_{\mathrm{h}}\right)^{-1} \\
& \mathrm{LE}=\rho \frac{L_{\mathrm{s}} k^{2} u\left(q-q_{\mathrm{s}}\right)}{\left(\ln \frac{z}{z_{0 \mathrm{~m}}}\right)\left(\operatorname{In} \frac{z}{z_{0 q}}\right)}\left(\Phi_{\mathrm{m}} \Phi_{v}\right)^{-1},
\end{aligned}
$$

where $\rho$ is the air density (in $\mathrm{kg} \mathrm{m}^{-3}$ ) at $4670 \mathrm{ma.s.1}$. at AWS 1 and calculated using the ideal gas equation $\left(\rho=\frac{P_{\text {atm }}}{R_{\mathrm{a}} T}\right.$, where $R_{\mathrm{a}}$ is the specific gas constant for dry air and $P_{\text {air }}$ is given by the measurements and around $565 \mathrm{hPa}$ ). $C_{\mathrm{P}}$ is the specific heat capacity for air at constant pressure $\left(C_{\mathrm{p}}=C_{\mathrm{pd}}\right.$ $(1+0.84 q)$ with $C_{\mathrm{pd}}=1005 \mathrm{~J} \mathrm{~kg}^{-1} \mathrm{~K}^{-1}$, the specific heat capacity for dry air at constant pressure), $k$ is the von Karman constant $(k=0.4)$ and $L_{\mathrm{s}}$ is the latent heat of sublimation of snow or ice $\left(L_{\mathrm{s}}=2.834 \times 10^{6} \mathrm{~J} \mathrm{~kg}^{-1}\right)$. Furthermore, $q$ is the mean specific humidity (in $\mathrm{g} \mathrm{kg}^{-1}$ ) of the air at the height $z$ and $q_{\mathrm{s}}$ is the mean specific humidity at surface. $z_{0 T}$ and $z_{0 q}$ are the surface roughness parameters for temperature and humidity, respectively. To compute turbulent fluxes (Eqs. 7 and 8), it is assumed that the temperature is equal to $T_{\mathrm{S}_{-} \text {mod }}$ at $z_{0 T}$ and that the air is saturated with respect to $T_{\text {S_mod }}$ at $z_{0 q}$. The last assumption helps to calculate surface specific humidity $q_{\mathrm{s}}$. The non-dimensional stability functions for momentum $\left(\Phi_{\mathrm{m}}\right)$, for heat $\left(\Phi_{\mathrm{h}}\right)$ and moisture $\left(\Phi_{v}\right)$ can be expressed in terms of $R i_{b}$ (e.g. Favier et al., 2011).

$$
\begin{aligned}
& \text { For } R i_{\mathrm{b}} \text { positive (stable) }:\left(\Phi_{\mathrm{m}} \Phi_{\mathrm{h}}\right)^{-1}=\left(\Phi_{\mathrm{m}} \Phi_{v}\right)^{-1} \\
& =\left(1-5 R i_{\mathrm{b}}\right)^{2}
\end{aligned}
$$

For $R i_{\mathrm{b}}$ negative (unstable) $:\left(\Phi_{\mathrm{m}} \Phi_{\mathrm{h}}\right)^{-1}=\left(\Phi_{\mathrm{m}} \Phi_{v}\right)^{-1}$

$$
=\left(1-16 R i_{\mathrm{b}}\right)^{0.75} \text {. }
$$

The lower and upper limits of $R i_{b}$ were fixed at -0.40 and 0.23 , respectively beyond which all turbulence is suppressed (Denby and Greuell, 2000; Favier et al., 2011).

\subsubsection{Roughness parameters}

The aerodynamic $\left(z_{0 \mathrm{~m}}\right)$ and scalar roughness lengths $\left(z_{0 T}\right.$ and $z_{0 q}$ ) play a pivotal role in bulk method as the turbulent fluxes are very sensitive to the choice of these surface roughness lengths (e.g. Hock and Holmgren, 1996; Wagnon et al., 1999). In several studies (e.g. Wagnon et al., 1999; Favier et al., 2004), the surface roughness lengths were all taken to be equal $\left(z_{0 \mathrm{~m}}=z_{0 T}=z_{0 q}\right)$ and used as calibration parameters. In the present study, the $z_{0 \mathrm{~m}}$ was calculated assuming a $\log$ arithmic profile for wind speed between both the levels of measurements in neutral conditions (e.g. Moore, 1983): 
$z_{0 \mathrm{~m}}=\exp \left(\frac{u_{2} \ln z_{1}-u_{1} \ln z_{2}}{u_{2}-u_{1}}\right)$,

where $u_{1}$ and $u_{2}$ are the wind velocities measured at the lower and higher levels $z_{1}$ and $z_{2}$, respectively. For $-0.005<R i_{b}<0.005$ (11\% of our total data set, at halfhourly time step), it was assumed that conditions are neutral, and half-hourly values for $z_{0 \mathrm{~m}}$ were calculated using Eq. (11). Half-hourly values of $z_{0 \mathrm{~m}}$ were assessed separately for ice and snow surfaces, based on field observations (snowcovered surface between 16 September 2012 and 17 January 2013 and ice-covered surface the rest of the time). The $z_{0 \mathrm{~m}}$ was calculated as $0.016 \mathrm{~m}$ (with STD of $0.026 \mathrm{~m}$ ) and $0.001 \mathrm{~m}(0.003 \mathrm{~m})$ for ice and snow surfaces, respectively. During the summer-monsoon, the surface is covered with hummocks and gullies and $z_{0 \mathrm{~m}}$ is large whereas in winter, snow covers all surface irregularities and fills up the gullies (Fig. 3) providing small values of $z_{0 \mathrm{~m}}$. The ratio between roughness lengths $\left(z_{0 \mathrm{~m}} / z_{0 q}\right.$ and $\left.z_{0 \mathrm{~m}} / z_{0 T}\right)$ depends on the Reynolds number of the flow according to Andreas (1987) polynomials. For high Reynolds numbers (aerodynamically rough flows), the polynomials suggested by Smeets and Van den Broeke (2008) for hummocks were used. The respective mean values obtained for $z_{0 T}$ and $z_{0 q}$ are identical and equal to $0.004 \mathrm{~m}$ over rough icy surfaces, and $0.001 \mathrm{~m}$ over smooth snow surfaces. These values are similar to $z_{0 \mathrm{~m}}$ values for snow-smooth surfaces as already observed by Bintanja and Van den Broeke (1995) and lower for icy-rough surfaces as pointed out by many authors (e.g. Andreas, 1987; Hock and Holmgren, 1996; Meesters et al., 1997).

\section{Results}

\subsection{Analysis of the meteorological conditions at AWS1}

In order to understand the seasonal evolution of the physical processes controlling the mass balance of the glacier, different representative periods for various seasons of 60 days duration were selected for inter-seasonal comparisons, based on the meteorological conditions observed in Sect. 2.4 and the available data set at AWS1. The selected representative periods are post-monsoon (1 October to 29 November 2012), winter (1 December 2012 to 29 January 2013) and the summer-monsoon (8 July to 5 September 2013). The same length of 60 days of each representative period was chosen for justified comparison among different seasons. Unfortunately, data were not available for pre-monsoon. Measurements ( $T_{\text {air }}, \mathrm{RH}, u$ and WD) recorded at the upper-level sensors were used for the analysis, since the records from the lower-level sensors have longer data gap because of early burial of sensors. A summary of the mean variables measured in different representative periods at AWS1 is given in Table 3.

Figure 7 shows the daily averages of $T_{\text {air }}, u, \mathrm{RH}, \mathrm{LWI}$, LWO, SWI, SWO, STOA, cloud factor, $\alpha_{\text {acc }}$ and snowfalls for all three representative periods. The meteorological variables show strong seasonality and day-to-day variability. The last panels of Fig. 7 represent the daily snowfall amounts (with a data gap between 1 and 8 October 2012) at AWS1 site extracted from SR50A data (by applying a fresh snow density of $200 \mathrm{~kg} \mathrm{~m}^{-3}$ ). Post-monsoon and winter periods are cold with mean $T_{\text {air }}$ and $T_{\text {S_obs }}$ always far below freezing point (Fig. 7 and Table 3). During the post-monsoon period mean $u$ and $\alpha_{\text {acc }}$ progressively increased (mean $u=4.7 \mathrm{~m} \mathrm{~s}^{-1}$ and $\left.\alpha_{\text {acc }}=0.73\right)$ and reached their highest values in the winter period (mean $u=4.9 \mathrm{~m} \mathrm{~s}^{-1}$ and $\alpha_{\text {acc }}=0.79$ ). $\alpha_{\text {acc }}$ remains almost constant in the winter period showing the persistent snow cover. Snowfalls in the post-monsoon period were frequent but generally very light $(<10 \mathrm{~mm}$ w.e. $)$, whereas the winter period received a substantial amount of snow (the heaviest snowfalls were observed on 16 December 2012, and 17, 18 January 2013 with 32, 44 and $80 \mathrm{~mm}$ w.e., respectively). These snowfall events are associated with high $\mathrm{RH}, \alpha_{\text {acc }}$, cloud factor and LWI values. Obviously, an abrupt decrease of SWI (consequently low SWO) is noticed during snowfall events. Most of the time, due to very cold and dry high-elevation atmosphere, LWI remains very low during both the periods, with mean values of 205 and $189 \mathrm{~W} \mathrm{~m}^{-2}$ in post-monsoon and winter periods, respectively (Table 3). An analysis of Fig. 7 showed that overcast days with high cloud factor, high RH, increased LWI and decreased SWI are evident during all three representative periods.

The summer-monsoon period is warm and calm with relatively high humidity (Fig. 7 and Table 3). SWI is high during the summer-monsoon period (however, the maximum SWI is expected in pre-monsoon, Sect. 2.4.1) with a mean value of $248 \mathrm{~W} \mathrm{~m}^{-2}$ (Table 3). Most SWI (81\%) is absorbed by the glacier because of the lowest values of $\alpha_{\text {acc }}$ (mean value $=0.19$ ) consequently low SWO. The low and almost constant $\alpha_{\text {acc }}$ indicates that the glacier ice was exposed all the time. The surface remains almost continuously in melting condition, as shown by constantly maximal LWO values. Although the summer-monsoon period is characterized by the highest value of cloud factor (0.4), few snowfall events are observed from the SR50A at AWS1 site. Given that $T_{\text {air }}$ was above freezing point, the precipitation might have occurred in the form of rain most of the time. Due to warm, humid and cloudy conditions, LWI is much higher in the summermonsoon than during the other two studied seasons, with a mean value of $300 \mathrm{~W} \mathrm{~m}^{-2}$ (Table 3).

Post-monsoon and winter periods are characterized by high wind speeds (mean $u$ values of 4.7 and $4.9 \mathrm{~m} \mathrm{~s}^{-1}$, respectively; Table 3 ). In the summer-monsoon period $u$ is quite stable $\left(\mathrm{STD}=0.5 \mathrm{~m} \mathrm{~s}^{-1}\right.$ ) and gusts at minimum strength with a mean value of $3.6 \mathrm{~m} \mathrm{~s}^{-1}$. Chhota Shigri Glacier is situated in an almost north-south oriented valley and the AWS1 site is bounded by steep valley walls to the east and west (Fig. 1). The scatter plots of $u$ with $T_{\text {air }}$ and WD over all of the observation periods at half-hourly timescale were plotted following Oerlemans (2010). Figure 8a mostly 

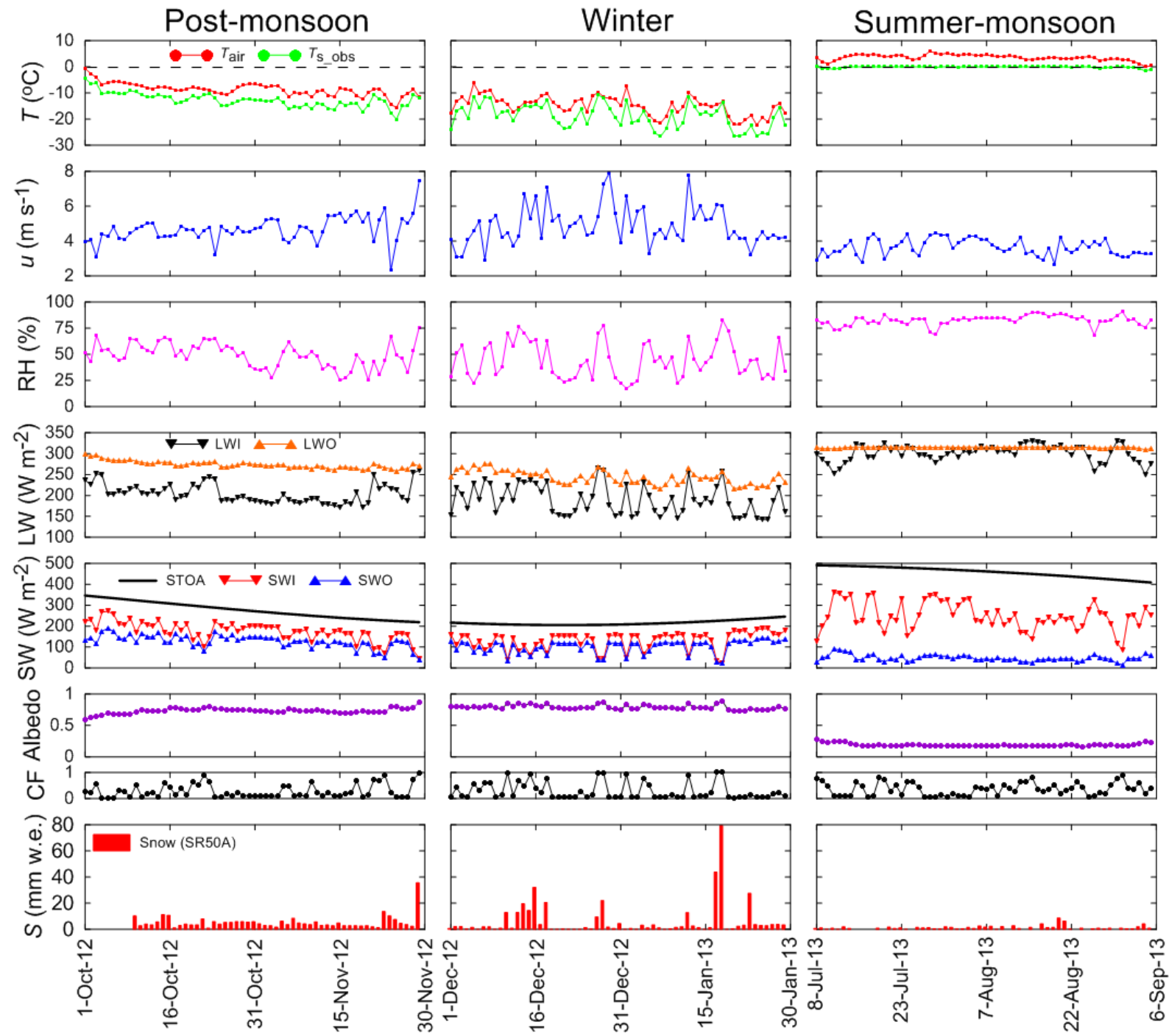

Figure 7. Daily meteorological variables recorded at AWS1 (4670 ma.s.1.) as representative of post-monsoon (1 October to 29 November 2012), winter (1 December to 29 January 2013) and summer-monsoon (8 July to 5 September 2013) periods. Also shown (lower panel) are the snowfalls derived from SR50A data at AWS1.

shows a linear relationship between $T_{\text {air }}$ above melting point and $u$ at AWS1 site showing that increasing $u$ is associated with increasing near-surface $T_{\text {air }}$, indicative of katabatic forcing, whereas Fig. $8 \mathrm{~b}$ reveals a mean down-glacier wind (WD of 200-210 ) most of the time.

Wind direction, measured at AWS1, indicates that there is a persistent down-glacier wind coming from south to southwest $\left(200-210^{\circ}\right)$ during post-monsoon and winter periods (Fig. 9). In winter, the half-hourly mean $u$ reaches up to $10 \mathrm{~m} \mathrm{~s}^{-1}$ compared to $8 \mathrm{~m} \mathrm{~s}^{-1}$ in the post-monsoon period. During both post-monsoon and winter periods the glacier surface is snow covered (with high $\alpha_{\text {acc }}$, Fig. 7) and a downglacier wind is maintained by the negative radiation budget (Sect. 4.2) of the snow surface which gives rise to cooling to the near-surface air, generating katabatic flow (Grisogono and Oerlemans, 2002). Further, on Chhota Shigri Glacier, in the summer-monsoon period the wind regime is quite remarkable. During the summer-monsoon, the down-glacier wind, coming from south to southwest $\left(200-210^{\circ}\right)$ is relatively weak and might be the result of katabatic forcing, which is typical for many valley glaciers (Van den Broeke, 1997). Occasionally, wind also tends to come from the southeast $\left(160^{\circ}\right)$, in the direction of a large hanging glacier (Fig. 1). The upcoming valley wind coming from the northeast $\left(50^{\circ}\right)$, blowing against the down-glacier wind, is weak at the AWS1 site and appears only during the summer-monsoon periods when the down-glacier wind is comparatively weak. As a cumulative result of upcoming valley and down-glacier winds, a wind from $110^{\circ}$ is also observed. 
Table 3. 60-day means (standard deviations) of meteorological and SEB variables measured or computed at AWS1 (4670 m a.s.1.) on Chhota Shigri Glacier for different representative periods. The symbols for variables are described either in the text or in Table 1. SWN, LWN and $R$ are net shortwave, longwave and all-wave radiations, respectively.

\begin{tabular}{|c|c|c|c|}
\hline Variable & $\begin{array}{l}\text { Post-monsoon } \\
\text { (1 Oct 2012-29 Nov 2012) }\end{array}$ & $\begin{array}{l}\text { Winter } \\
\text { (1 Dec 2012-29 Jan 2013) }\end{array}$ & $\begin{array}{l}\text { Summer-monsoon } \\
\text { (8 Jul 2013-5 Sep 2013) }\end{array}$ \\
\hline$T_{\text {air }}\left({ }^{\circ} \mathrm{C}\right)$ & $-8.6(2.5)$ & $-14.8(3.7)$ & $3.6(1.2)$ \\
\hline $\mathrm{RH}(\%)$ & $49(12)$ & $44(17)$ & $82(5)$ \\
\hline$u\left(\mathrm{~m} \mathrm{~s}^{-1}\right)$ & $4.7(0.7)$ & $4.9(1.1)$ & $3.6(0.5)$ \\
\hline STOA $\left(\mathrm{W} \mathrm{m}^{-2}\right)$ & $276(39)$ & $216(11)$ & $458(25)$ \\
\hline $\mathrm{SWI}\left(\mathrm{W} \mathrm{m}^{-2}\right)$ & $175(46)$ & $130(44)$ & $248(67)$ \\
\hline $\operatorname{SWO}\left(\mathrm{W} \mathrm{m}^{-2}\right)$ & $127(31)$ & $101(32)$ & $47(15)$ \\
\hline$\alpha_{\mathrm{acc}}$ & $0.73(0.04)$ & $0.79(0.04)$ & $0.19(0.02)$ \\
\hline Cloud factor & $0.28(0.26)$ & $0.29(0.33)$ & $0.36(0.24)$ \\
\hline LWI $\left(\mathrm{W} \mathrm{m}^{-2}\right)$ & $205(23)$ & $189(36)$ & $300(20)$ \\
\hline $\mathrm{LWO}_{\bmod }\left(\mathrm{W} \mathrm{m}^{-2}\right)$ & $274(9)$ & $243(16)$ & $315(1)$ \\
\hline$T_{\mathrm{S} \_\bmod }\left({ }^{\circ} \mathrm{C}\right)$ & $-9.7(2.1)$ & $-17.8(4.3)$ & $-0.2(0.3)$ \\
\hline $\operatorname{SWN}\left(\mathrm{W} \mathrm{m}^{-2}\right)$ & $48(17)$ & $29(13)$ & $202(53)$ \\
\hline $\operatorname{LWN}\left(\mathrm{W} \mathrm{m}^{-2}\right)$ & $-69(19)$ & $-54(24)$ & $-14(19)$ \\
\hline$R\left(\mathrm{~W} \mathrm{~m}^{-2}\right)$ & $-21(19)$ & $-25(15)$ & $187(44)$ \\
\hline$H\left(\mathrm{~W} \mathrm{~m}^{-2}\right)$ & $10(13)$ & $28(23)$ & $31(10)$ \\
\hline $\operatorname{LE}\left(\mathrm{W} \mathrm{m}^{-2}\right)$ & $-45(9)$ & $-27(11)$ & $11(13)$ \\
\hline$G\left(\mathrm{~W} \mathrm{~m}^{-2}\right)$ & $1(1)$ & $0(1)$ & $4(5)$ \\
\hline $\mathrm{SW}_{\mathrm{sub}}\left(\mathrm{W} \mathrm{m}^{-2}\right)$ & $-10(3)$ & $-3(2)$ & $-40(11)$ \\
\hline$H+\mathrm{LE}\left(\mathrm{W} \mathrm{m}^{-2}\right)$ & $-36(11)$ & $1(11)$ & $42(21)$ \\
\hline$F_{\text {surface }}\left(\mathrm{W} \mathrm{m}^{-2}\right)$ & $-56(16)$ & $-24(28)$ & $233(59)$ \\
\hline Precipitation (mm w.e. $\left.\mathrm{d}^{-1}\right)$ & $0.6(1.0)$ & $5.0(8.9)$ & $0.5(0.9)$ \\
\hline Snow (mm w.e. $\left.\mathrm{d}^{-1}\right)$ & $5.3(5.1)$ & $6.3(13.0)$ & $1.4(1.6)$ \\
\hline Total melting (mm w.e. $\left.\mathrm{d}^{-1}\right)$ & $0.6(1.7)$ & $0.0(0.0)$ & $61.3(14.9)$ \\
\hline Subl. $(-) /$ re-subl. $(+)\left(\mathrm{mm} \text { w.e. } \mathrm{d}^{-1}\right)^{*}$ & $-1.4(0.3)$ & $-0.8(0.3)$ & $0.3(0.4)$ \\
\hline
\end{tabular}

* Negative for sublimation, positive for re-sublimation.
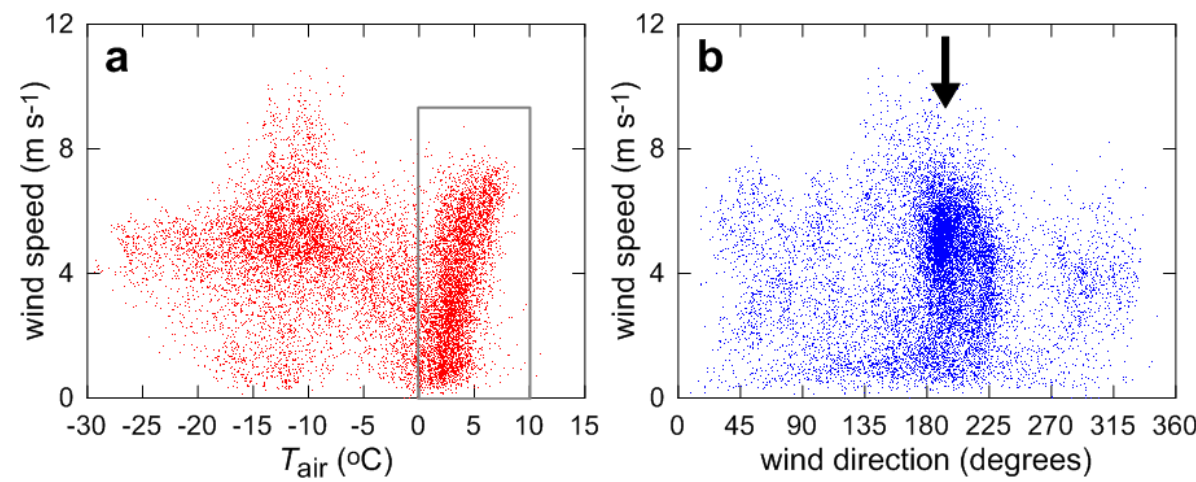

Figure 8. Scatter plots showing relations between $u, T_{\text {air }}$ and WD. In both panels (a and $\left.\mathbf{b}\right)$ all the available measurements are shown, and every dot represents a half-hourly mean value. The inset in (a) highlights the relationship between $u$ and $T_{\text {air }}$ above $0{ }^{\circ} \mathrm{C}$. The arrow in (b) indicates the direction of the local flow line of the glacier.

AWS1 is surrounded by steep N-S valley walls. In order to analyse the impact of synoptic-scale circulation at AWS1 site, we compared the wind directions at AWS1 with those at $450 \mathrm{hPa}$ pressure level obtained from High Asia Reanalysis data (HAR, Maussion et al., 2014) at hourly scale. HAR wind data are available at $10 \mathrm{~km}$ resolution for different pressure levels for the 2001-2012 period. The pressure level of $450 \mathrm{hPa}$ (equivalent to $\sim 6350 \mathrm{~m}$ a.s.l.) has been chosen as representative of the synoptic circulation above the glacier (whose highest elevation is $6263 \mathrm{~m}$ a.s.l.). Synoptic (HAR, 

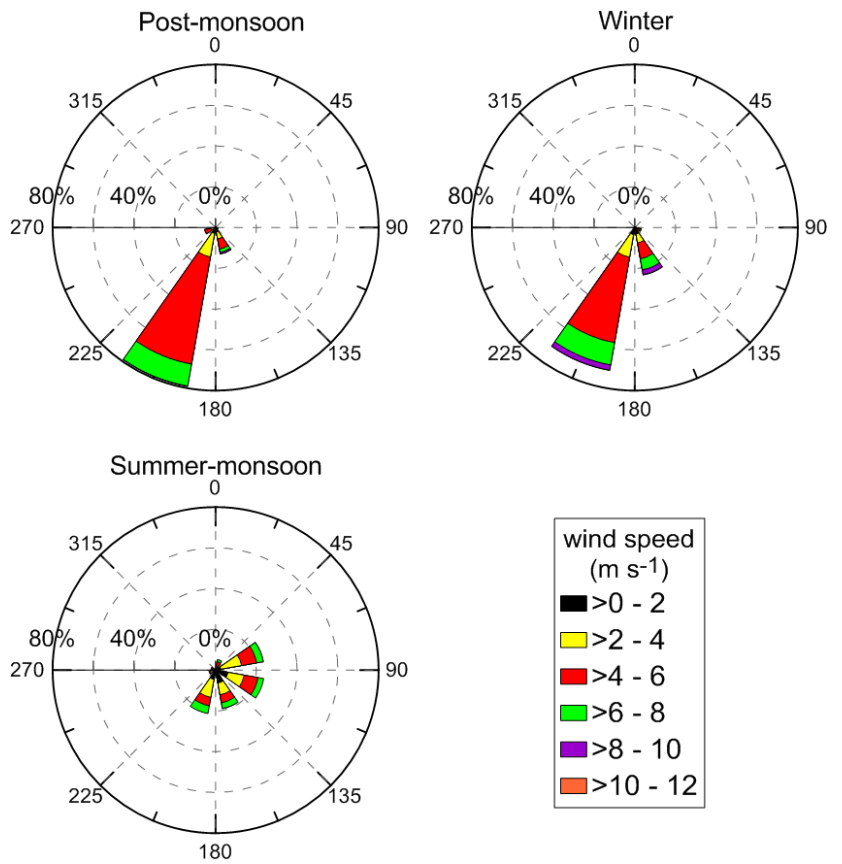

Figure 9. WD and $u$ (half-hourly means) at AWS1 for postmonsoon, winter- and summer-monsoon representative periods. The frequency of WD is expressed as percentage over the entire observational period (indicated on the radial axes).

$450 \mathrm{hPa}$ ) wind comes mainly from west or southwest directions, depending on the season. Given that on its eastern side the glacier is bordered by a high $\mathrm{N}-\mathrm{S}$ ridge (often above $6000 \mathrm{~m}$ a.s.1.), this synoptic wind may be deflected down to the valley providing winds parallel to the katabatic flow at AWS1. Therefore at AWS1 site the wind coming from south to southwest is probably the result of both katabatic and synoptic effects.

\subsection{Mean values of the SEB components}

Mean SEB values for three representative periods are presented in Fig. 10 and are reported in Table 3. The results indicate that the mean seasonal net shortwave radiation (SWN) is highly variable from $29 \mathrm{~W} \mathrm{~m}^{-2}$ in winter to $202 \mathrm{~W} \mathrm{~m}^{-2}$ in the summer-monsoon (Table 3). Besides the seasonal changes in sun inclination, the main reason for the seasonal variability of SWN is the contrast in surface albedo in different periods (Table 3). Seasonal variations in net longwave radiations $\left(\mathrm{LWN}=\mathrm{LWI}-\mathrm{LWO}_{\bmod }\right)$ are rather low; post-monsoon and winter periods show minimum values of LWN (mean $=-69$ and $-54 \mathrm{~W} \mathrm{~m}^{-2}$, respectively), while the maximum was obtained for the summer-monsoon period $\left(\right.$ mean $\left.=-14 \mathrm{~W} \mathrm{~m}^{-2}\right)$ when $T_{\mathrm{s}_{-} \bmod }\left(\right.$ mean $\left.=-0.2{ }^{\circ} \mathrm{C}\right)$ remains close to the melting point and coincides with warm and humid conditions associated with dense cloud cover leading to high values of LWI. The net radiation heat flux $R$ $(=\mathrm{SWN}+\mathrm{LWN})$ was negative in post-monsoon and winter periods, giving rise to near-surface air cooling, with mean values of -21 and $-25 \mathrm{Wm}^{-2}$, respectively whereas in the summer-monsoon, it was the main heat source with a mean value of $187 \mathrm{~W} \mathrm{~m}^{-2}$. During all representative periods, the atmosphere transported heat towards the glacier surface in the form of $H$. The highest contribution of $H$ (associated with the highest $T_{\mathrm{s}_{-} \text {mod }}$, Table 3 ) was in the summermonsoon with a mean value of $31 \mathrm{~W} \mathrm{~m}^{-2}$ (Table 3 ). LE was continuously negative in post-monsoon and winter periods with mean values of -45 and $-27 \mathrm{~W} \mathrm{~m}^{-2}$, respectively. Therefore, the surface lost mass through sublimation (corresponding to respective mean daily rates of -1.4 and $-0.8 \mathrm{~mm}$ w.e. $\mathrm{d}^{-1}$ ). However, in the summer-monsoon period, a sign shift in LE from negative to positive occurred. The relatively high $T_{\text {air }}$ and RH (Table 3 ) led to a reversal of the specific humidity gradient and therefore a positive LE for a melting valley glacier (Oerlemans, 2000). Because of this positive LE, the glacier gained mass through condensation or re-sublimation of moist air at the surface (Table 3 ). Assuming re-sublimation as the main process, an amount of $0.3 \mathrm{~mm}$ w.e. $\mathrm{d}^{-1}$ mass gain is calculated during the summermonsoon period. The amount of shortwave radiation penetrating below the surface $\left(\mathrm{SW}_{\mathrm{sub}}\right)$ is slightly negative during post-monsoon and winter seasons while in the summermonsoon it was highest in agreement with the highest values of SWN. When subsurface ice layers were at $0^{\circ} \mathrm{C}$, this energy amount was converted into subsurface melt occurring in the first layer of the model, leading to runoff. At the daily timescale, the conductive heat flux $(G)$ was mostly negligible except during the summer-monsoon when it was slightly positive and was responsible for a small energy gain during the night in the upper layers of the glacier, which resulted in melt when these layers were at melting point soon after sunrise.

As a result of SEB, positive melt heat flux ( $\left.F_{\text {surface }}\right)$, with almost the same seasonal oscillation as SWN (Fig. 10), occurred only in the summer-monsoon period when melting conditions were prevailing all the time, leading to a mean daily melt rate of $61.3 \mathrm{~mm}$ w.e. $\mathrm{d}^{-1}$. During the summermonsoon period SWN accounted for $87 \%$ of the total heat flux and was the most important heat-flux component for surface melting. $R$ was estimated as $80 \%$ of the total heat flux that was complemented with turbulent sensible, latent and conductive heat fluxes with a share of 13,5 and $2 \%$, respectively. During post-monsoon period the glacier started cooling down (mean $F_{\text {surface }}=-56 \mathrm{~W} \mathrm{~m}^{-2}$ ) with a little melting (mean daily rate of $0.6 \mathrm{~mm}$ w.e. $\mathrm{d}^{-1}$ ) occurring during the noon hours only, when occasionally $T_{\mathrm{S} \_ \text {mod }}$ reached $0{ }^{\circ} \mathrm{C}$, while in winter period the glacier was too cold (the highest half hourly $T_{\mathrm{S} \_ \text {mod }}$ was $-4.23^{\circ} \mathrm{C}$ ) to experience any melting (mean $F_{\text {surface }}=-24 \mathrm{~W} \mathrm{~m}^{-2}$ ). 

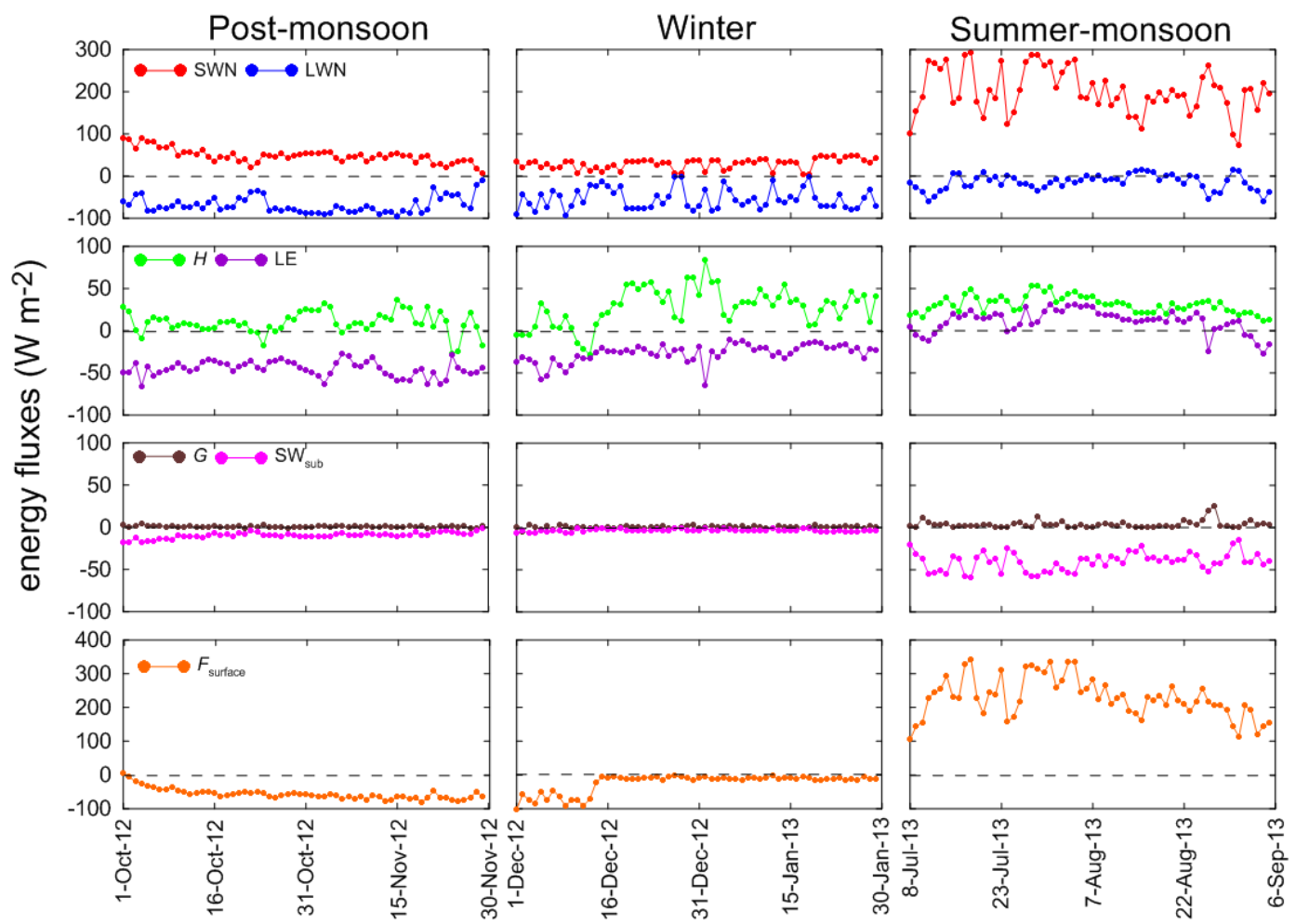

Figure 10. Daily values of the surface energy fluxes at AWS1 (4670 m a.s.1.) as representative of post-monsoon (1 October to 29 November 2012), winter (1 December to 29 January 2013) and summer-monsoon (8 July to 5 September 2013) periods. SWN, LWN, $H$, LE, $G$, $\mathrm{SW}_{\text {sub }}$ and $F_{\text {surface }}$ are the net shortwave radiation, the net longwave radiation, the turbulent sensible and latent heat fluxes, the conductive heat flux, the shortwave radiation penetrating below the surface, and the amount of energy available at the surface, respectively.

\subsection{Model validation}

The model provides a heat transfer at half-hourly time step to the glacier superficial layers that can be turned into melt when the modelled surface temperature, $T_{\mathrm{S}_{-} \text {mod, }}$, is at $0^{\circ} \mathrm{C}$. When the computed snow or ice temperature exceeds $0^{\circ} \mathrm{C}$, the corresponding energy excess is also converted into melt. Subsurface melt contributes to runoff when it occurs in the first layer of the model. Another way to lose/gain mass is from sublimation/re-sublimation. The amount of sublimation/re-sublimation (mw.e.) was computed from calculated LE divided by the latent heat of sublimation $\left(2.834 \times 10^{6} \mathrm{~J} \mathrm{~kg}^{-1}\right)$ and the density of water $\left(1000 \mathrm{~kg} \mathrm{~m}^{-3}\right)$ when the half-hourly mean LE flux was negative/positive. During the summer-monsoon, the glacier lost mass at a daily mean melt rate of $61.3 \mathrm{~mm}$ w.e. $\mathrm{d}^{-1}$, while a mass gain of $0.3 \mathrm{~mm}$ w.e. $\mathrm{d}^{-1}$ was observed through resublimation (Table 3 ). Sublimation was negligible during the summer-monsoon.

To validate the SEB model, computed ablation (melt + sublimation - re-sublimation) was compared with the ablation measured at stake no. VI in the field (Sect. 2.3). The correlation between computed ablation from the SEB equation and measured ablation at stake no. VI is strong $\left(r^{2}=0.98, n=9\right.$ periods), indicating the robustness of the model. Although the computed ablation is 1.15 times higher than the measured one (Fig. 11a), this difference $(15 \%$ overestimation) is acceptable given the overall uncertainty of $140 \mathrm{~mm}$ w.e. in stake ablation measurements (Thibert et al., 2008). Furthermore, surface temperatures at half-hourly time step ( $\left.T_{\text {s_mod }_{-}}\right)$were calculated by the model without using measured LWO (or associated surface temperatures, $T_{\mathrm{s}_{\mathrm{B}} \mathrm{obs}}$ ). Figure $11 \mathrm{~b}$ shows that the half-hourly $T_{\mathrm{S}_{\mathrm{O}} \mathrm{obs}}$ and $T_{\mathrm{S} \_ \text {mod }}$ are highly correlated $\left(r^{2}=0.96\right)$, with an average difference of $1.2^{\circ} \mathrm{C}$. This temperature difference corresponds to a mean difference of $4.6 \mathrm{~W} \mathrm{~m}^{-2}$ between $\mathrm{LWO}_{\text {mod }}$ and observed LWO, showing that the modelled surface heat budget is reasonably computed. Moreover, if we run the model with an additional $2 \mathrm{~cm}$ snow layer at the surface when measured albedo values are higher than 0.7 , the mean difference between $T_{\mathrm{S}_{-} \text {mod }}$ and $T_{\mathrm{S} \_ \text {obs }}$ drops to $0.2{ }^{\circ} \mathrm{C}$, showing that this difference does not come from a bad performance of the model, but from a bad estimation of the surface state (snow or ice) and thus of precipitation during low-intensity events (explaining the bi-modal scatter observed in Fig. 11b i.e. surface state correctly reproduced or not). Thus when the surface state is appropriately assessed, the model provides a good estimation of $T_{\mathrm{s} \_ \text {mod. }}$. In conclusion, given that the model is able to properly compute surface temperature or 

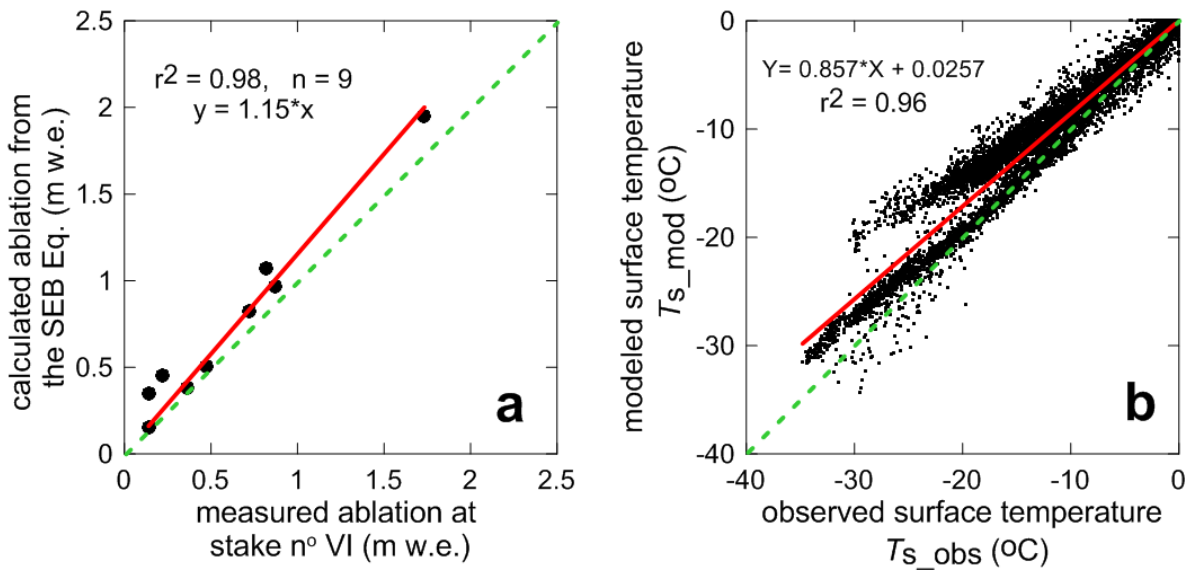

Figure 11. Comparison between ablation computed from the SEB equation and measured at stake no. VI (a) during several few-day to fewweek periods of 2012 and 2013 summers where field measurements are available. (b) Comparison between modelled half-hourly ( $\left.T_{\mathrm{S} \_ \text {mod }}\right)$ and observed $\left(T_{\mathrm{S} \_ \text {obs }}\right)$ surface temperatures over the whole simulation period. Also shown are the $1: 1$ line (dashed line) and the regression line (solid line).

ablation at point scale, we believe that it can reasonably calculate all the SEB fluxes.

\subsection{Mean diurnal cycle of the meteorological variables and SEB components}

The mean diurnal cycles of the meteorological variables and SEB components for all three representative periods are shown in Fig. 12. Mean diurnal cycles of $T_{\mathrm{s}} \bmod$ (equivalent to $\mathrm{LWO}_{\text {mod }}$ ) and $T_{\text {air }}$ showed that the glacier was in freezing conditions during post-monsoon and winter periods all the time (Fig. 12) while in the summer-monsoon, $T_{\mathrm{s}_{-} \bmod }$ is always at melting point in agreement with consistently positive $T_{\text {air }}$. Occasionally, for some days, half-hourly mean $T_{\text {air }}$ (not shown here) may drop below freezing point during the night in the summer-monsoon and climb above freezing point during noon hours in the post-monsoon period. A wind speed maximum is observed in the afternoon hours during all the representative periods, which is consistent with $T_{\text {air }}$. This is a common phenomenon on valley glaciers, with $u$ increasing in the afternoon (e.g. Van den Broeke, 1997; Greuell and Smeets, 2001) as a consequence of an increased glacier wind due to a stronger $T_{\text {air }}$ deficit in the afternoon. A wind speed minimum is observed in the morning time of post-monsoon but no reason for this could be identified.

For all the representative periods, $R$ is negative at night (indicating longwave radiative cooling of the surface) and positive during the day time. However, during the summermonsoon period the night values of $R$ are slightly less negative as the radiative cooling is attenuated due to enhanced $\mathrm{RH}, T_{\text {air }}$, cloudiness, and in turn high LWI. In daytime, $R$ is much higher during the summer-monsoon than other periods, mainly because of exposed low-albedo ice at the glacier surface enhancing the absorption of solar radiation, which is already high due to annual maximum of the solar angle.
$H$ and LE show similar daily cycles in post-monsoon and winter periods. During the night, $H$ remains permanently high $\left(\sim 50 \mathrm{~W} \mathrm{~m}^{-2}\right)$ and starts decreasing in the morning as the surface is heated up with $R$ (Fig. 12). This daily cycle of $H$ is in agreement with the daily cycle of $R i_{b}$, showing stable conditions almost all day long $\left(R i_{b}>0\right.$ except $4 \mathrm{~h}$ in the middle of the afternoon in winter), with very stable conditions in the night, and moderately stable during the day or even unstable in the afternoon in winter. LE is negative in the night, decreases in the morning and shows the minimum values during early afternoon hours which are in agreement with increasing wind speed and stronger vertical gradients of specific humidity in the vicinity of the surface. During the summer-monsoon, both $H$ and LE are positive (heat supplied to the surface) and follow a similar trend, but $H$ attains its peak approximately $2 \mathrm{~h}$ before LE. $H$ shows a peak at $\sim$ 14:00 LT with positive $T_{\text {air }}$ and wind speed maximum (Fig. 12) whereas LE remains close to $0 \mathrm{~W} \mathrm{~m}^{-2}$ until noon and increases with an afternoon wind speed maximum. The stability of the surface boundary layer is not very different from that observed during the other periods, highly stable at night, but moderately stable during the day due to the occurrence of warm up-valley winds blowing over a melting surface in summer-monsoon. Thus, LE is positive during the summer-monsoon giving rise to re-sublimation in afternoon and early night hours.

$\mathrm{SW}_{\text {sub }}$ mirrors the daily cycle of SWN but is attenuated as part of SWN is absorbed by the surface, and part is transferred to the underlying layers, following an exponential extinction. During winter and post-monsoon, negative values of $G$ are compensated by positive values in the afternoon (after 16:00 LT, when surface temperature begins to decrease) or early night hours, leading to insignificant values of this heat flux at daily scale. During the summer-monsoon, $G$ is equal 

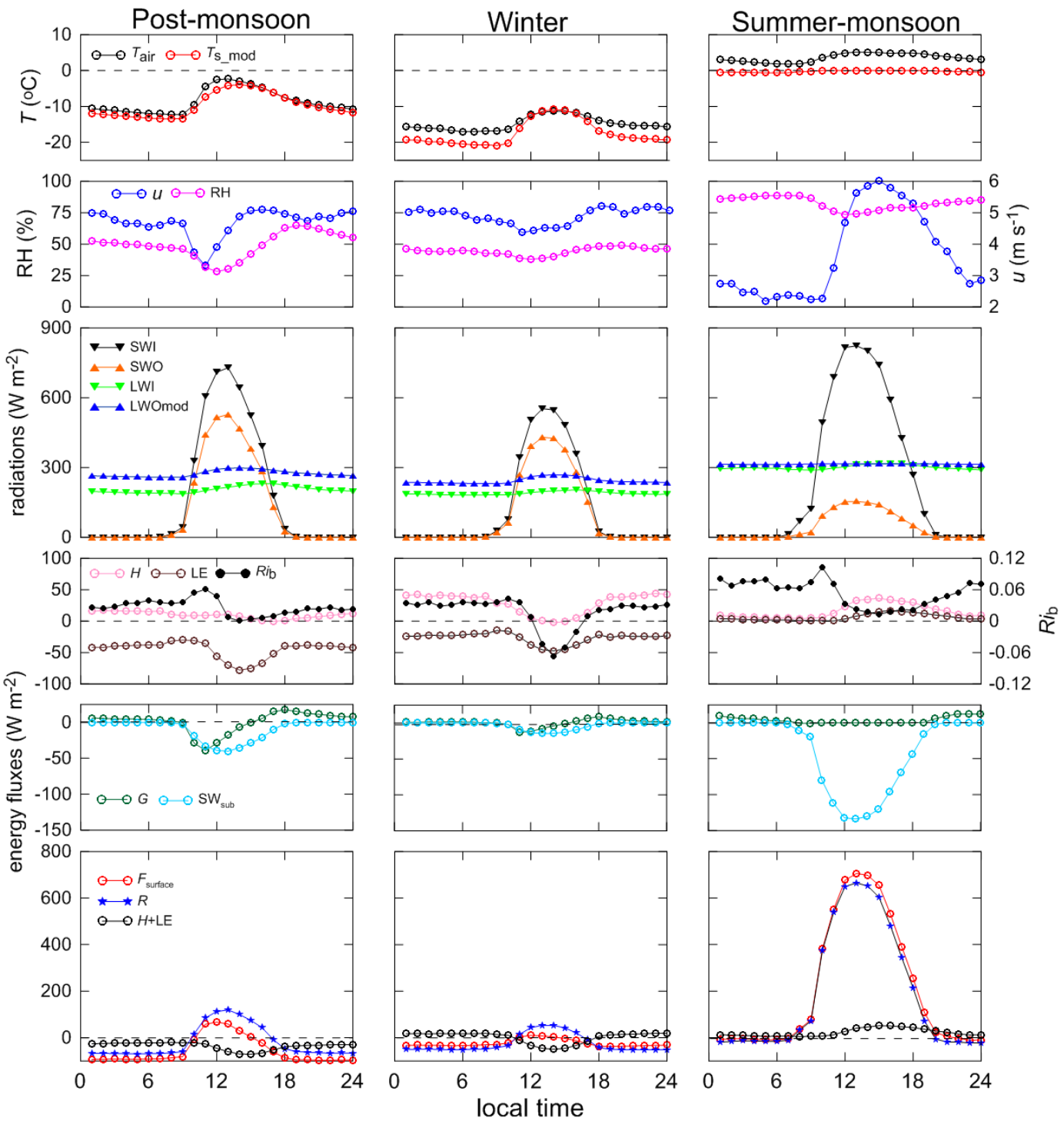

Figure 12. Mean diurnal cycle of meteorological and SEB variables at AWS1 (4670 m a.s.1.) as representative of post-monsoon (1 October to 29 November 2012), winter (1 December to 29 January 2013) and summer-monsoon (8 July to 5 September 2013) periods.

to zero during daytime and only positive at night when internal layers of the glacier at the melting point try to compensate the nocturnal surface cooling and thus bring energy to the surface.

During post-monsoon and winter periods, in the night, $F_{\text {surface }}$ is negative, and a cold front penetrates into the superficial layers of the glacier. However, $F_{\text {surface }}$ is rather low as $R$ is mostly compensated by $H+\mathrm{LE}$ except during noon hours when $F_{\text {surface }}$ switches to slightly positive values. Heat is then transferred during a few hours of the day to the ice/snow pack whose temperature rises but not enough to reach melting conditions ( $T_{\mathrm{S}_{\_} \text {mod }}$ remains below $0^{\circ} \mathrm{C}$ ) (Fig. 12). During the summer-monsoon period, $F_{\text {surface }}$ follows the diurnal cycle of $R$ providing energy up to $710 \mathrm{~W} \mathrm{~m}^{-2}$ to the glacier surface at around 12:00 LT. This energy is consumed for melting process as the surface is melting continuously (Fig. 12). Unfortunately, the data set does not cover the pre-monsoon. But during this season, the heat transferred to the glacier progressively increases as net shortwave radiation enhances in agreement with the rise in solar angle, as well as the decreasing surface albedo. This heat is first used to warm up the surface layers of the glacier until $T_{\mathrm{S} \_ \text {mod }}$ reaches $0{ }^{\circ} \mathrm{C}$, then melting starts. 


\section{Discussion}

\subsection{Control of the summer-monsoon snowfalls on melting}

\subsubsection{Comparison between 2012 and 2013 melting periods}

The impact of ISM has already been analysed on Tibetan glaciers (e.g. Fujita and Ageta, 2000; Yang et al., 2011; Mölg et al., 2012, 2014) but it is still not well understood in the Himalaya. Previously, based on a degree-day approach, Azam et al. (2014) suggested that winter precipitation and summer temperature are almost equally important drivers controlling the mass balance pattern of Chhota Shigri Glacier. Here this topic is addressed by analysing the surface melting on Chhota Shigri Glacier with the summer-monsoon precipitations using a more detailed SEB approach. Based on the available data set, we selected the same length of the summer-monsoon period (15 August to 30 September) from 2012 and 2013 years to compare the evolution of the computed cumulative melting (Fig. 13). Given that the SR50A at AWS1 site has a data gap between 8 September and 9 October 2012 and that this sensor cannot record rain events, daily precipitations, collected at glacier base camp (3850 m a.s.1.), are used in this analysis. These precipitation values are extrapolated at AWS1 assuming a zero-precipitation gradient and are considered as rain (snow) at AWS1 site when $T_{\text {air }}$ at AWS1 is above (below) $1{ }^{\circ} \mathrm{C}$ (e.g. Wagnon et al., 2009). In the summer-monsoon 2012, Chhota Shigri Glacier received one important snowfall of $25 \mathrm{~mm}$ w.e. (equivalent to $125 \mathrm{~mm}$ of fresh snow applying a density of $200 \mathrm{~kg} \mathrm{~m}^{-3}$ ) during the period 17-19 September. This snowfall abruptly changed the surface conditions by varying the surface albedo from 0.19 to 0.73 (Fig. 13a). Therefore, the energy $F_{\text {surface }}$ available at the glacier surface suddenly dropped from $123 \mathrm{~W} \mathrm{~m}^{-2}$ on 16 September to $14 \mathrm{~W} \mathrm{~m}^{-2}$ on 17 September as shown by the sharp change in the melting rate (slope of the melting curve on Fig. 13a) associated with this specific snowfall event. The effect is also evident on $T_{\mathrm{S}_{-} \text {mod }}$ evolution. The daily number of hours with $T_{\mathrm{s} \text { mod }}>-1^{\circ} \mathrm{C}$ decreased from 24 to $6 \mathrm{~h}$ and remained around this value throughout, showing that melting, which was continuous before the snowfall event, is reduced to a few hours of the day. During the summer-monsoon 2013, the situation was different as the snowfalls were more sporadic and never big enough to efficiently slow down the melting. Consequently, a shift in the slope in the melting curve is not observed as was the case in mid-September 2012. Indeed, the light snowfalls, observed from 13 to 16 September 2013 and from 24 to 30 September 2013, were only able to protect the glacier from high melting for some days but could not maintain a persistent snow cover as in midSeptember 2012. Ice was again exposed at the surface as revealed by low albedo values $(\sim 0.38)$ observed again a few days after the snowfalls. Mean $T_{\text {air }}$ and the daily number of
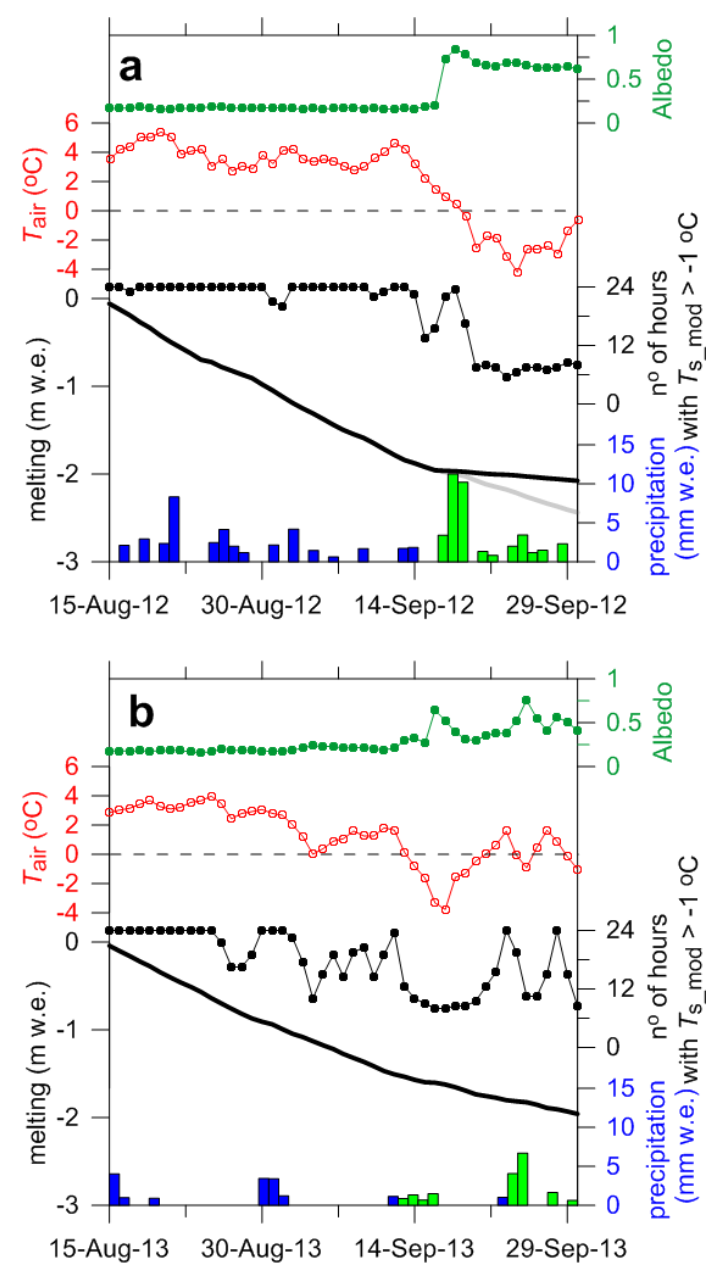

Figure 13. Comparison of computed cumulative melting (black thick line) between 15 August and 30 September from summers 2012 (a) and 2013 (b). Also shown are the mean $T_{\text {air }}$ (red open dots), the number of hours in a day when $T_{\mathrm{s} \bmod }$ is $>-1^{\circ} \mathrm{C}$ (black dots), daily albedo (dark green dots) and the precipitations as rain/snow obtained from records at base camp (blue and green bars, respectively). The grey line in (a) is the computed cumulative melting between 15 August and 30 September 2012 assuming a constant surface albedo of 0.19 .

hours with $T_{\mathrm{s}_{-} \bmod }>-1{ }^{\circ} \mathrm{C}$ again rose up, maintaining the high melt rates. As a consequence, at point scale, although the cumulative melting between 15 August and 30 September was very similar in 2012 and 2013 (2.08 and $1.96 \mathrm{~m}$ w.e., respectively), the main difference comes from the distribution of the melting along the considered period. Although the melt rates in 2012 were higher than 2013 during the first 31 days, an early snowfall efficiently slowed down the melting, however it was slightly less intense but more regular in 2013.

In order to better quantify the albedo effect of the mid-September 2012 snowfalls on the glacier melting, the model was run again assuming a constant albedo $(=0.19)$ 
over the entire 2012 summer period, all other meteorological variables being unchanged meanwhile (Fig. 13a). As expected, the overall melting with constant albedo is enhanced $(2.44 \mathrm{mw}$.e.) with a moderate difference of $0.36 \mathrm{~m}$ w.e. ( $+17 \%$ compared to a simulation with real albedo) between 15 August and 30 September 2012, but very significant when considering only the period when the observed albedo differs from 0.19 (i.e. after 17 September 2012). Certainly, between 17 and 30 September, the computed melting using a constant albedo (0.19) is $0.48 \mathrm{~m}$ w.e., 4 times higher than that with the observed albedo ( $0.12 \mathrm{~m}$ w.e.). Even though Chhota Shigri Glacier is a winteraccumulation type glacier, this analysis highlights and quantifies the role of snowfall events during the summer-monsoon on albedo and, in turn on melting.

This effect has already been described in other parts of the world. Sicart et al. (2011) suggested that melting on Zongo Glacier, Bolivia is reduced by wet season snowfalls via the albedo effect during the melt season. In the central Tibetan Plateau, Fujita and Ageta (2000), Fujita (2008a, b) and Zhang et al. (2013) indicated that the glacier surface mass balance was closely related to the summer-monsoon precipitation seasonality and phase (snow versus rain). Mölg et al. (2012) analysed the impact of ISM on Zhadang Glacier using their fully distributed SEB/mass balance model between 2009 and 2011 and concluded that the timing of monsoon onset leaves a clear footprint on the glacier via the albedo effect. Recently Mölg et al. (2014) extended this analysis at the decadal scale and opined that the intensity of ISM onset together with MLW dynamics are important in determining the annual mass balance of Zhadang Glacier.

\subsubsection{Impact of the summer-monsoon snowfalls on glacier-wide mass balance}

In order to investigate the impact of the summer-monsoon snowfalls on glacier-wide mass balance, the annual glacierwide mass balances between 2002 and 2013 were compared with the largest summer-monsoon daily snowfalls of the corresponding season. These snowfalls have been extrapolated using daily precipitation data from Bhuntar meteorological station (1092 ma.s.1.), assuming no precipitation gradient and applying the daily lapse rate between Bhuntar and glacier calculated by Azam et al. (2014) with the idea that if the precipitation is in the form of snow (threshold temperature equal to $1^{\circ} \mathrm{C}$ ) at $4400 \mathrm{~m}$ a.s.l. (below $4400 \mathrm{~m}$ a.s.l. the glacier is totally debris covered), the whole glacier is covered by summer monsoonal snow.

The choice of using precipitation data from Bhuntar meteorological station to assess precipitation on the glacier might seem unfortunate at first glance because, as already discussed in Sect. 2.4.2., both sites are separated by an orographic barrier inducing a different precipitation distribution. However, these sites are only $50 \mathrm{~km}$ away from each other, and we believe that meteorological conditions are not totally decoupled

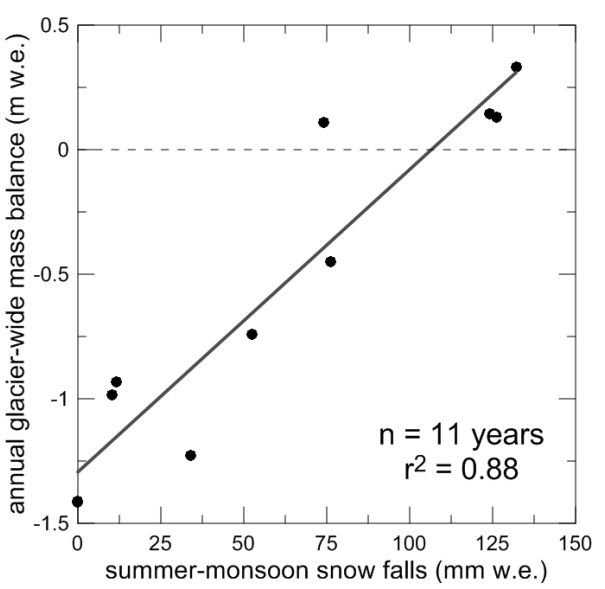

Figure 14. Annual glacier-wide mass balance as a function of the sum of the three largest summer-monsoon daily snowfalls assessed from precipitation record from Bhuntar meteorological station (see text for details) between 2002 and 2013.

between the windward and the leeward side of the mountain range, especially in the case of precipitation events strong enough to cross this orographic barrier. Fortunately, Wulf et al. (2010) conducted a thorough study using the precipitation data of 80 stations from the Northwest Himalaya including Chhota Shigri area and concluded that in Baspa Valley ( $\sim 100 \mathrm{~km}$ southeast to Chhota Shigri Glacier) "The two most prominent 5-day-long erosional events account for $50 \%$ of the total 5-year suspended sediment flux and coincide with synoptic scale monsoonal rainstorms. This emphasizes the erosional impact of the ISM as the main driving force for erosion processes in the orogenic interior, despite more precipitation falling during the winter season."

The best relationship is obtained when considering the sum of the three most important daily snowfall records of the corresponding summer-monsoon (Fig. 14). The correlation is strong $\left(r^{2}=0.88, n=11\right.$ years) and suggests that the summer-monsoon snowfall events play a key role in controlling the mass balance of the glacier. Such snowfalls cover the whole glacier implying that the albedo of the whole ablation area can suddenly switch from low to high values (ice to snow surfaces). Consequently, melting is abruptly reduced or even stopped at the glacier surface for several weeks or even for the rest of the ablation season that usually ends around mid-October in years without such strong summermonsoon snowfalls. Thus, the intensity of such summermonsoon snowfalls is among the most important drivers controlling the annual mass balance of Chhota Shigri Glacier.

Azam et al. (2014), using a degree-day approach, showed that winter precipitation and summer temperature are equally important drivers controlling the glacier-wide mass balance of Chhota Shigri Glacier. This present analysis extends this knowledge a step further, showing that the summer-monsoon snowfalls also play an important role in controlling the 
annual mass balance of Chhota Shigri Glacier. Indeed, the summer-monsoon air temperature is as crucial as summer precipitation mainly because it controls the amount of rain versus snow received at the glacier surface and in turn, has an important control on glacier albedo and thus on the amount of shortwave radiation absorbed by the glacier surface, which is the main heat source for Himalayan glaciers.

\subsection{Comparison of the SEB of Chhota Shigri Glacier with that of other glaciers in High Mountain Asia}

In this section some key features of the energy fluxes responsible for the ablation on glaciers in High Mountain Asia are discussed in the light of the SEB results obtained on Chhota Shigri Glacier, as well as from some previously published studies. Table 4 shows an up-to-date compilation of SEB studies from High Mountain Asia glaciers coming from ablation zones of different glaciers during summer ablation periods.

As already highlighted on High Mountain Asia glaciers (Yang et al., 2011; Mölg et al., 2012; Zhang et al., 2013; Sun et al., 2014), the present study also showed that SWN is the largest source of energy to the glacier surface and mainly controls the temporal variability of melting, whereas LWN is the greatest energy loss - moderate during the summermonsoon when $\mathrm{LWO}_{\text {mod }}$ is almost compensated by maximum LWI due to warm, humid and cloudy atmosphere, and high during the rest of the year when LWI reaches minimum values (Fig. 10 and Table 3). SWN is inversely dependent on surface albedo. At AWS1 site on Chhota Shigri Glacier, during the summer-monsoon period, precipitation often occurs in liquid form and surface albedo is relatively constant (Fig. 7). During such conditions SWN is driven by cloud factor (Fig. 7). However, when precipitation occurs in solid phase (Fig. 13), the surface albedo abruptly changes and controls the SWN and in turn, melting. The sum of SWN and LWN, $R$, provides $>80 \%$ energy flux to the glacier surface during the summer-monsoon for all High Mountain Asia glaciers (Table 4).

All the studied sites, described in Table 4, are on the debris-free ablation area. A negative contribution (in \%) is assigned to negative heat fluxes in order to have the resulting flux $F_{\text {surface }}$ equal to $100 \%$. Sensible turbulent heat flux is always positive and provides energy to the glacier surface, complementing net radiation flux. However, its contribution to $R$ ranges from $7 \%$ on Laohugou Glacier No. 12, western Qilian, China, to the maximum of $23 \%$ on Zhadang Glacier, central Tibetan Plateau over the corresponding observation periods (Table 4). During the summer-monsoon, LE is positive on Chhota Shigri Glacier due to warm and humid air at the glacier surface, giving rise to re-sublimation at the surface. This phenomenon has already been observed on AX010 Glacier located in an ISM-dominated region, central Himalaya, Nepal, where Kayastha et al. (1999) measured a positive LE between 25 May and 25 September 1978 in the ablation area. On Parlung Glacier No. 4, Southeast Tibetan Plateau, however, the mean LE was slightly negative from 21 May to 8 September 2009 (Table 4), while it was continuously positive with a mean value of $8 \mathrm{~W} \mathrm{~m}^{-2}$ during the core summer-monsoon between 25 June and 21 August 2009 because of the considerably high temperature and relative humidity associated with the summer-monsoon circulation over this period (Table 2 in Yang et al., 2011). Conversely, in the central Tibetan Plateau, where dry conditions prevail, on Zhadang Glacier, LE is continuously negative at the monthly scale (Mölg et al., 2012) but at the daily timescale it was slightly positive during the core monsoon for a few days when the air temperature and relative humidity were the highest (Figs. 2 and 5 in Zhang et al., 2013). Sun et al. (2014) also showed that on Laohugou Glacier No. 12, western Qilian Mountains, LE is negative throughout the summer season (1 June to 30 September 2011), and rarely becomes positive (only on 2 and 3 July). Similarly on Xixibangma Glacier, south central Tibetan Plateau, and Keqicar Glacier, Southwest Tianshan, LE was found to be negative during the observation period, indicating sublimation. From the present analysis (Table 4), it can be surmised that, on High Mountain Asia glaciers, sublimation predominates in the summermonsoon over the ablation zone of the glaciers that are less affected by the ISM and submitted to drier conditions than those directly affected like Chhota Shigri Glacier, where LE brings a significant amount of energy at the glacier surface, in the form of re-sublimation. The conductive heat flux is most of the time negligible compared to the other terms of the SEB, even during the summer-monsoon where it slightly contributed to melt.

\section{Conclusions}

In the Indian Himalaya where meteorological observations are short and scarce, the meteorological data set recorded since August 2009 at $4863 \mathrm{~m}$ a.s.l. on a lateral moraine of Chhota Shigri Glacier (AWS2) is one of the longest ever recorded data sets at high elevation. Mean monthly meteorological conditions at AWS2 show large month-to-month variability. A warm and calm summer-monsoon with high relative humidity from June to September and a cold and windy winter season with comparatively less humidity from December to March were identified. A pre-monsoon from April to May and a post-monsoon from October to November with intermediate conditions were also defined. Precipitation records at glacier base camp suggest that Chhota Shigri Glacier is a winter-accumulation type glacier receiving around $80 \%$ of its annual precipitation from MLW in winter and $20 \%$ from ISM; but longer precipitation records at glacier site are still needed to confirm this feature.

A physically based energy balance experiment, using a model computing surface and subsurface heat fluxes, was 


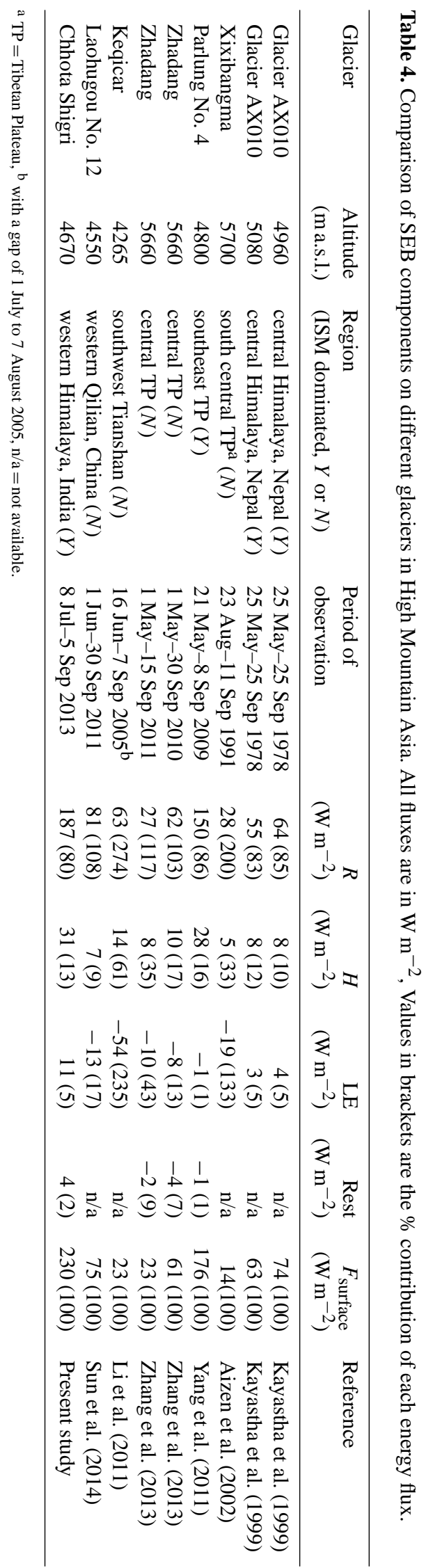

carried out to understand the melting processes on Chhota Shigri Glacier based on the forcing data over two separate periods from 13 August 2012 to 3 February 2013 and from 8 July to 3 October 2013 recorded at an in situ meteorological station (AWS1, $4670 \mathrm{~m}$ a.s.1.) in the ablation zone. The roughness length for momentum was calculated separately for ice and snow surfaces as 0.016 and $0.001 \mathrm{~m}$, respectively whereas roughness lengths for temperature and humidity were derived from the Reynolds number and the roughness length for momentum. Net shortwave radiation was highly variable with the lowest mean value $\left(29 \mathrm{~W} \mathrm{~m}^{-2}\right)$ in winter to the highest $\left(202 \mathrm{~W} \mathrm{~m}^{-2}\right)$ in the summer-monsoon period, while net longwave radiation exerted lower seasonality with minimum values in post-monsoon and winter periods ( -69 and $-54 \mathrm{~W} \mathrm{~m}^{-2}$, respectively) and maximum in the summer-monsoon period $\left(-14 \mathrm{~W} \mathrm{~m}^{-2}\right)$. During the summer-monsoon period the melting conditions with high $T_{\text {s_mod }}\left(\right.$ mean $\left.=-0.2^{\circ} \mathrm{C}\right)$ coincides with warm and humid conditions, associated with intense cloud covers, leading to high values of LWI and thus high net longwave radiation is observed. Net all-wave radiation was negative in postmonsoon and winter periods, indicative of radiative cooling of the glacier surface, whereas in the summer-monsoon, it was the main heat source for melting. Through the entire observation period, the atmosphere transported heat towards the glacier surface in the form of sensible heat flux. An interesting feature observed in latent heat flux evolution was it being continuously negative in post-monsoon and winter periods, indicating predominantly sublimation; while in the summermonsoon period, it switched to positive values indicating resublimation at the glacier surface. The result from the SEB equation suggests that energy was available for melting in the summer-monsoon period only. Net all-wave radiation was the main heat flux towards surface with $80 \%$ contribution while $H, \mathrm{LE}$ and $G$ shared 13,5 and $2 \%$ of total heat flux, respectively.

This study highlights the impact of the summer-monsoon snowfalls on glacier mass balance. Snowfall events during the summer-monsoon play an important role on melting via surface albedo. The intensity of these snowfalls during ablation period abruptly changes the surface conditions from ice to snow, slowing down the melting rates. Therefore, these snowfall events are among the most important drivers controlling the annual mass balance of Chhota Shigri Glacier. The summer-monsoon air temperature, controlling the precipitation phase (rain versus snow and thus albedo), also counts, indirectly, among the most important drivers for the glacier mass balance.

A comparison of the SEB measured at the ablation zone of Chhota Shigri Glacier with those of other glaciers in High Mountain Asia shows that net shortwave radiation flux is the largest energy source and mainly controls the melt energy to the glacier surface whereas net longwave radiation flux is the greatest energy loss. In High Mountain Asia, sublimation predominates in the summer-monsoon over the ablation 
zone of the glaciers less affected by the ISM and submitted to drier conditions than those directly affected like Chhota Shigri Glacier, where LE brings a significant amount of energy at the glacier surface in the form of re-sublimation.

The good validation of the present model (comparison between modelled and observed ablation and surface temperature data) indicates that the model is reliable enough to make robust calculations of surface energy balance. In the future, this study would be useful to calibrate spatially distributed energy- and mass-balance models at glacier as well as regional scale. These models can be used to predict the future of water supply using different climate change projections.

Acknowledgements. This work has been supported by IRD as a part of M. F. Azam's PhD. Authors are also grateful to DSTIFCPAR/CEFIPRA project no. 3900-W1, the French Service d'Observation GLACIOCLIM as well as the Department of Science and Technology (DST), Government of India. We thank the Indian Meteorological Department (IMD), New Delhi for providing the data from Bhuntar meteorological station. We thank Jawaharlal Nehru University, New Delhi for providing all the facilities to carry out this work. M. F. Azam is grateful to Rajdeep Singh for improving the content of the paper, Romain Biron for sharing his knowledge and experience about AWS assembling and Fabien Maussion for providing High Asia Reanalysis data. We are also grateful to the two anonymous referees, whose thorough comments significantly improved the paper as well as Mauri Pelto, Thomas Mölg, Koji Fujita and one anonymous reviewer for providing constructive comments and suggestions.

Edited by: V. Radic

\section{References}

Ageta, Y. and Higuchi, K.: Estimation of mass balance components of a summer-accumulation type glacier in the Nepal Himalaya, Geogr. Ann. A, 66, 249-255, 1984.

Aizen, V. B., Aizen, E. M., and Nikitin S. A.: Glacier regime on the northern slope of the Himalaya (Xixibangma glaciers), Quatern. Int., 97-98, 27-39, doi:10.1016/S1040-6182(02)00049-6, 2002.

Andreas, E. L.: A theory for the scalar roughness and the scalar transfer coefficients over snow and sea ice, Bound.-Lay. Meteorol., 38, 159-184, 1987.

Arck, M. and Scherer, D.: Problems in the determination of sensible heat flux over snow, Geogr. Ann. A, 84, 157-169, 2002.

Azam, M. F., Wagnon, P., Ramanathan, AL., Vincent, C., Sharma, P., Arnaud, Y., Linda, A., Pottakkal, J. G., Chevallier, P., Singh, V. B., and Berthier, E.: From balance to imbalance: a shift in the dynamic behaviour of Chhota Shigri Glacier (Western Himalaya, India), J. Glaciol., 58, 315-324, doi:10.3189/2012JoG11J123, 2012.

Azam, M. F., Wagnon, P., Vincent, C., Ramanathan, A. L., Linda, A., and Singh, V. B.: Reconstruction of the annual mass balance of Chhota Shigri Glacier (Western Himalaya, India) since 1969, Ann. Glaciol., 55, 69-80, doi:10.3189/2014AoG66A104, 2014
Bahr, D. B., Dyurgerov, M., and Meier, M. F.: Sea-level rise from glaciers and ice caps: A lower bound, Geophys. Res. Lett., 36, L03501, doi:10.1029/2008GL036309, 2009.

Bintanja, R. and Van den Broeke, M. R.: The surface energy balance of Antarctic snow and blue ice, J. Appl. Meteorol., 34, 902-926, 1995.

Bintanja, R., Jonsson, S., and Knap W.: The annual cycle of the surface energy balance of Antarctic blue ice, J. Geophys. Res., 102, 1867-1881, doi:10.1029/96JD01801, 1997.

Bolch, T., Kulkarni, A., Kääb, A., Huggel, C., Paul, F., Cogley, J. G., Frey, H., Kargel, J. S., Fujita, K., Scheel, M., Bajracharya, S., and Stoffel, M.: The State and Fate of Himalayan Glaciers, Science, 336, 310-314, 2012.

Bookhagen, B. and Burbank, D. W.: Topography, relief, and TRMM-derived rainfall variations along the Himalaya, Geophys. Res. Lett., 33, L08405, doi:10.1029/2006GL026037, 2006.

Bookhagen, B. and Burbank, D. W.: Toward a complete Himalayan hydrological budget: Spatiotemporal distribution of snowmelt and rainfall and their impact on river discharge, J. Geophys. Res. 115, F03019, doi:10.1029/2009JF001426, 2010.

Bookhagen, B., Thiede, R. C., and Strecker, M. R.: Abnormal monsoon years and their control on erosion and sediment flux in high, arid northwest Himalaya, Earth Planet. Sc. Lett, 231, 131-146, 2005.

Brutsaert, B.: Evaporation in the Atmosphere: Theory, History and Application, Kluwer Acad., Norwell, Mass, 299 pp., 1982.

Cogley, J. G.: Present and future states of Himalaya and Karakoram glaciers, Ann. Glaciol., 52, 69-73, 2011.

Denby, B. and Greuell, W.: The use of bulk and profile methods for determining surface heat fluxes in the presence of glacier winds, J. Glaciol., 46, 445-452, 2000.

Dorsey, N. E.: Properties of Ordinary Water-Substance in All Its Phases: Water-Vapor, Water, and All the Ices, Reinhold, New York, 1940.

Douville, H., Royer, J. F., and Mahfouf, J. F.: A new snow parameterization for the Météo-France climate model, Part I: Validation in standalone experiments, Clim. Dynam., 12, 21-35, doi:10.1007/BF00208760, 1995.

Favier, V., Wagnon, P., Chazarin, J. P., Maisincho, L., and Coudrain, A.: One-year measurements of surface heat budget on the ablation zone of Antizana Glacier 15, Ecuadorian Andes, J. Geophys. Res., 109, D18105, doi:10.1029/2003JD004359, 2004.

Favier, V., Agosta, C., Genthon, C., Arnaud, L., Trouvillez, A., and Gallee, H.: Modeling the mass and surface heat budgets in a coastal blue ice area of Adelie Land, Antarctica, J. Geophys. Res., 116, F03017, doi:10.1029/2010JF001939, 2011.

Fujita, K.: Influence of precipitation seasonality on glacier mass balance and its sensitivity to climate change, Ann. Glaciol., 48, 88-92, 2008a.

Fujita, K.: Effect of precipitation seasonality on climatic sensitivity of glacier mass balance, Earth Planet. Sc. Lett., 276, 14-19, 2008b.

Fujita, K. and Ageta, Y.: Effect of summer accumulation on glacier mass balance on the Tibetan Plateau revealed by mass-balance model, J. Glaciol., 46, 244-252, 2000.

Gardelle, J., Berthier, E., Arnaud, Y., and Kääb, A.: Region-wide glacier mass balances over the Pamir-Karakoram-Himalaya during 1999-2011, The Cryosphere, 7, 1263-1286, doi:10.5194/tc7-1263-2013, 2013. 
Giesen, R. H., Andreassen, L. M., van den Broeke, M. R., and Oerlemans, J.: Comparison of the meteorology and surface energy balance at Storbreen and Midtdalsbreen, two glaciers in southern Norway, The Cryosphere, 3, 57-74, doi:10.5194/tc-3-57-2009, 2009.

Giesen, R. H., Andreassen, L. M., Oerlemans, J., and Van den Broeke, M. R.: Surface energy balance in the ablation zone of Langfjordjøkelen, an arctic, maritime glacier in northern Norway, J. Glaciol., 60, 57-70, doi:10.3189/2014JoG13J063, 2014.

Greuell, W. and Smeets, P.: Variations with elevation in the surface energy balance on the Pasterze (Austria), J. Geophys. Res., 106, 31717-31727, 2001.

Greuell, W., Knap, W. H., and Smeets, P. C.: Elevational changes in meteorological variables along a mid-latitude glacier during summer, J. Geophys. Res., 102, 25941-25954, 1997.

Grisogono, B. and Oerlemans, J.: Justifying the WKB approximation in pure katabatic flows, Tellus A, 54, 453-463, 2002.

Heid, T. and Kääb, A.: Repeat optical satellite images reveal widespread and long term decrease in land-terminating glacier speeds, The Cryosphere, 6, 467-478, doi:10.5194/tc-6-4672012, 2012.

Hock, R. and Holmgren, B.: Some aspects of energy balance and ablation of Storglaciaren, Northern Sweden, Geogr. Ann. A, 78, 121-131, 1996.

Hoinkes, H. C.: Measurements of ablation and heat balance on alpine glacier, J. Glaciol., 2, 497-501, 1953.

Immerzeel, W. W., Pellicciotti, F., and Bierkens, M. F. P.: Rising river flows throughout the twenty-first century in two Himalayan glacierized watersheds, Nat. Geosci., 6, 742-745, 2013.

Iqbal, M.: An introduction to solar radiation, Academic Press, New York, 1983.

Kääb, A., Berthier, E., Nuth, C., Gardelle, J. and Arnaud, Y.: Contrasting patterns of early 21 st century glacier mass change in the Himalaya, Nature, 488, 495-498, doi:10.1038/nature11324, 2012.

Kaser, G., Großhauser, M., and Marzeion, B.: Contribution potential of glaciers to water availability in different climate regimes, P. Natl. Acad. Sci., 107, 20223-20227, doi:10.1073/pnas.1008162107, 2010.

Kayastha, R. B., Ohata, T., and Ageta, Y.: Application of mass balance model to a Himalayan glacier, J. Glaciol., 45, 559-567, 1999.

Klok, E. J. and Oerlemans, J.: Model study of the spatial distribution of the energy and mass balance of Morteratschgletscher, Switzerland, J. Glaciol., 48, 505-518, 2002.

Klok, E. J., Nolan, M., and Van den Broeke, M. R.: Analysis of meteorological data and the surface energy balance of McCall Glacier, Alaska, USA, J. Glaciol., 51, 451-461, 2005.

Koul, M. N. and Ganjoo, R. K.: Impact of inter- and intraannual variation in weather parameters on mass balance and equilibrium line altitude of Naradu Glacier (Himachal Pradesh), NW Himalaya, India, Climatic Change, 99, 119-139, doi:10.1007/s10584-009-9660-9, 2010.

Kuipers Munneke, P., van den Broeke, M. R., King, J. C., Gray, T., and Reijmer, C. H.: Near-surface climate and surface energy budget of Larsen C ice shelf, Antarctic Peninsula, The Cryosphere, 6, 353-363, doi:10.5194/tc-6-353-2012, 2012.

Lejeune, Y., Bertrand, J.-M., Wagnon, P., and Morin, S.: A physically based model of the year-round surface energy and mass balance of debris-covered glaciers, J. Glaciol., 59, 327-344, doi:10.3189/2013JoG12J149, 2013.

Li, J., Liu, S., Zhang, Y., and Shangguan, D.: Surface energy balance of Keqicar Glacier, Tianshan Mountains, China, during ablation period, Sci. Cold Arid Reg., 3, 197-205, doi:10.3724/SP.J.1226.2011.00197, 2011.

Maussion, F., Wei, Y., Huintjes, E., Pieczonka, T., Scherer, D., Yao, T., Kang, S., Bolch, T., Buchroithner, M., and Schneider, C.: Glaciological field studies at Zhadang Glacier (5500-6095 m), Tibetan Plateau, in: Workshop on the use of automatic measuring systems on glaciers - Extended abstracts and recommendations of the IASC Workshop, edited by: Tijm-Reijmer, C. H. and Oerlemans, J., 23-26 March 2011, Pontresina, Switzerland, Institute for Marine and Atmospheric Research, Utrecht University, the Netherlands, 62-68, 2011.

Maussion, F., Scherer, D., Mölg, T., Collier, E., Curio, J., and Finkelnburg, R.: Precipitation Seasonality and Variability over the Tibetan Plateau as Resolved by the High Asia Reanalysis, J. Climate, 27, 1910-1927, doi:10.1175/JCLI-D-13-00282.1, 2014.

Meesters, A. G. C. A., Bink, N. J. H., Vugts, F., Cannemeijer, F., and Henneken, E. A. C.: Turbulence observations above a smooth melting surface on the Greenland Ice Sheet, Bound.-Lay. Meteorol., 85, 81-110, 1997.

Mölg, T. and Hardy, D. R.: Ablation and associated energy balance of a horizontal glacier surface on Kilimanjaro, J. Geophys. Res., 109, 1-13, doi:10.1029/2003JD004338, 2004.

Mölg, T., Cullen, N. J., and Kaser, G.: Solar radiation, cloudiness and longwave radiation over low-latitude glaciers: implications for mass-balance modelling, J. Glaciol., 55, 292-302, doi:10.3189/002214309788608822, 2009.

Mölg, T., Maussion, F., Yang, W., and Scherer, D.: The footprint of Asian monsoon dynamics in the mass and energy balance of a Tibetan glacier, The Cryosphere, 6, 1445-1461, doi:10.5194/tc6-1445-2012, 2012.

Mölg, T., Maussion, F., and Scherer, D.: Mid-latitude westerlies as a driver of glacier variability in monsoonal High Asia, Nat. Clim. Change, 4, 68-73, 2014.

Moore, R.: On the use of bulk aerodynamic formulae over melting snow, Nord. Hydrol., 14, 193-206, 1983.

Nicholson, L. I., Prinz, R., Mölg, T., and Kaser, G.: Micrometeorological conditions and surface mass and energy fluxes on Lewis Glacier, Mt Kenya, in relation to other tropical glaciers, The Cryosphere, 7, 1205-1225, doi:10.5194/tc-7-1205-2013, 2013.

Oerlemans, J.: Analysis of a 3 year meteorological record from the ablation zone of Morteratschgletscher, Switzerland: energy and mass balance, J. Glaciol., 46, 571-579, 2000.

Oerlemans, J.: Glaciers and climate change, A. A. Balkema, The Nethrelands, 2001.

Oerlemans, J.: The Microclimate of Valley Glaciers, Igitur, Utrecht University, Utrecht Publishing \& Archiving Services, the Netherlands, 138 pp., 2010.

Oerlemans, J. and Klok, E.: Energy balance of a glacier surface: analysis of automatic weather station data from Morteratschgletscher, Switzerland, Arct. Antarct. Alp. Res., 34, 477-485, 2002.

Oke, T. R.: Boundary Layer Climates, 2nd Edn., Routledge, 423 pp., 1987.

Parry, M. L., Canziani, O. F., Palutikof, J. P., van der Linden, P. J., and Hanson, C. E.: Contribution of Working Group II to the 
Fourth Assessment Report of the Intergovernmental Panel on Climate Change 2007, Cambridge University Press, Cambridge, UK, New York, NY, USA, 2007.

Picard, G., Brucker, L., Fily, M., Gallée, H., and Krinner, G.: Modeling time series of microwave brightness temperature in Antarctica, J. Glaciol., 55, 537-551, doi:10.3189/002214309788816678, 2009.

Ramanathan, A. L.: Status Report on Chhota Shigri Glacier (Himachal Pradesh), Himalayan Glaciology Technical Report No. 1, Department of Science and Technology, Ministry of Science and Technology, New Delhi, 88 pp., 2011.

Reijmer, C. H. and Oerlemans, J.: Temporal and spatial variability of the surface energy balance in Dronning Maud Land, East Antarctica, J. Geophys. Res., 107, 4759-4770, doi:10.1029/2000JD000110, 2002.

Shekhar, M., Chand, H., Kumar, S., Srinivasan, K., and Ganju, A.: Climate-change studies in the western Himalaya, Ann. Glaciol., 51, 105-112, doi:10.3189/172756410791386508, 2010.

Sicart, J. E., Wagnon, P., and Ribstein, P.: Atmospheric controls of the heat balance of Zongo Glacier ( $16^{\circ} \mathrm{S}$, Bolivia), J. Geophys. Res., 110, D12106, doi:10.1029/2004JD005732, 2005.

Sicart, J. E., Hock, R., Ribstein, P., Litt, M., and Ramirez, E.: Analysis of seasonal variations in mass balance and meltwater discharge of the tropical Zongo Glacier by application of a distributed energy balance model, J. Geophys. Res., 116, D13105, doi:10.1029/2010JD015105, 2011.

Smeets, C. J. P. P. and Van den Broeke, M. R.: The parameterisation of scalar transfer over rough ice surfaces, Bound.-Lay. Meteorol., 128, 339-355, 2008.

Stocker, T. F., Qin, D., Plattner, G.-K., Tignor, M., Allen, S. K., Boschung, J., Nauels, A., Xia, Y., Bex, V., and Midgley, P. M.: IPCC: Climate Change 2013: The Physical Science Basis, in: Contribution of Working Group I to the Fifth Assessment Report of the Intergovernmental Panel on Climate Change, Cambridge University Press, Cambridge, UK and New York, NY, USA, 1535 pp., 2013.

Sun, W., Qin, X., Du, W., Liu, W., Liu, Y., Zhang, T., Xu, Y., Zhao, Q., Wu, J., and Ren, J.: Ablation modeling and surface energy budget in the ablation zone of Laohugou glacier No. 12, western Qilian mountains, China, Ann. Glaciol., 55, 111-120, doi:10.3189/2014AoG66A902, 2014.

Thayyen, R. J. and Gergan, J. T.: Role of glaciers in watershed hydrology: a preliminary study of a "Himalayan catchment", The Cryosphere, 4, 115-128, doi:10.5194/tc-4-115-2010, 2010.

Thibert, E., Blanc, R., Vincent, C., and Eckert, N.: Glaciological and volumetric mass balance measurements: Error analysis over 51 years for Glacier de Sarennes, French Alps, J. Glaciol., 54, 522-532, 2008.

Van den Broeke, M. R.: Momentum, heat and moisture budgets of the katabatic wind layer over a mid-latitude glacier in summer, J. Appl. Meteorol., 36, 763-774, 1997.

Van den Broeke, M. R., Van As, D., Reijmer, C. H., and Van de Wal, R. S. W.: Assessing and Improving the Quality of Unattended Radiation Observations in Antarctica, J. Atmos. Ocean. Tech., 21, 1417-1431, 2004. van den Broeke, M. R., Smeets, C. J. P. P., and van de Wal, R. S. W.: The seasonal cycle and interannual variability of surface energy balance and melt in the ablation zone of the west Greenland ice sheet, The Cryosphere, 5, 377-390, doi:10.5194/tc-5-377-2011, 2011.

Vincent, C., Ramanathan, Al., Wagnon, P., Dobhal, D. P., Linda, A., Berthier, E., Sharma, P., Arnaud, Y., Azam, M. F., Jose, P. G., and Gardelle, J.: Balanced conditions or slight mass gain of glaciers in the Lahaul and Spiti region (northern India, Himalaya) during the nineties preceded recent mass loss, The Cryosphere, 7, 569-582, doi:10.5194/tc-7-569-2013, 2013.

Wagnon, P., Ribstein, P., Francou, B., and Pouyaud, B.: Annual cycle of energy balance of Zongo Glacier, Cordillera Real, Bolivia, J. Geophys. Res., 104, 3907-3923, 1999.

Wagnon, P., Ribstein, P., Francou, B., and Sicart, J. E.: Anomalous heat and mass balance budget of Glaciar Zongo, Bolivia, during the 1997/98, El Nino year, J. Glaciol., 47, 21-28, 2001.

Wagnon, P., Sicart, J.-E., Berthier, E., and Chazarin, J.-P.: Wintertime high-altitude surface energy balance of a Bolivian glacier, Illimani, $6340 \mathrm{~m}$ above sea level, J. Geophys. Res., 108, 4177, doi:10.1029/2002JD002088, 2003.

Wagnon, P., Linda, A., Arnaud, Y., Kumar, R., Sharma, P., Vincent, C., Pottakkal, J. G., Berthier, E., Ramanathan, A., Hasnain, S. I., and Chevallier, P.: Four years of mass balance on Chhota Shigri Glacier, Himachal Pradesh, India, a new benchmark glacier in the western Himalaya, J. Glaciol., 53, 603-611, 2007.

Wagnon, P., Lafaysse, M., Lejeune, Y., Maisincho, L., Rojas, M., and Chazarin, J. P.: Understanding and modeling the physical processes that govern the melting of snow cover in a tropical mountain environment in Ecuador, J. Geophys. Res., 114, D19113, doi:10.1029/2009JD012292, 2009.

Wagnon, P., Vincent, C., Arnaud, Y., Berthier, E., Vuillermoz, E., Gruber, S., Ménégoz, M., Gilbert, A., Dumont, M., Shea, J. M., Stumm, D., and Pokhrel, B. K.: Seasonal and annual mass balances of Mera and Pokalde glaciers (Nepal Himalaya) since 2007, The Cryosphere, 7, 1769-1786, doi:10.5194/tc-7-17692013, 2013.

Weiers, S.: Zur Klimatologie des NW-Karakoram und angrenzender Gebiete, Statistische Analysen unter Einbeziehung von Wettersatellitenbildern und eines Geographischen Information systems (GIS), Bonner Geographische Abhandlungen 92, Geographisches Institut, Universitat Bonn, Bonn, Germany, 1995.

Wulf, H., Bookhagen, B., and Scherler, D.: Seasonal precipitation gradients and their impact on fluvial sediment flux in the Northwest Himalaya, Geomorphology, 118, 13-21, 2010.

Yang, W., Guo, X., Yao, T., Yang, K., Zhao, L., Li, S., and Zhu, M.: Summertime surface energy budget and ablation modeling in the ablation zone of a maritime Tibetan glacier, J. Geophys. Res., 116, D14116, doi:10.1029/2010JD015183, 2011.

Zhang, G., Kang, S., Fujita, K., Huintjes, E., Xu, J., Yamazaki, T., Haginoya, S., Wei, Y., Scherer, D., Schneider, C., and Yao, T.: Energy and mass balance of the Zhadang Glacier surface, central Tibetan Plateau, J. Glaciol., 213, 137-148, doi:10.3189/2013JoG12J152, 2013. 